\title{
Highly oxygenated organic molecules produced by the oxidation of benzene and toluene in a wide range of $\mathrm{OH}$ exposure and $\mathrm{NO}_{x}$ conditions
}

\author{
Xi Cheng ${ }^{1}$, Qi Chen ${ }^{1}$, Yong Jie $\mathrm{Li}^{2}$, Yan Zheng ${ }^{1}$, Keren Liao ${ }^{1}$, and Guancong Huang ${ }^{1}$ \\ ${ }^{1}$ State Key Joint Laboratory of Environmental Simulation and Pollution Control, BIC-ESAT and IJRC, \\ College of Environmental Sciences and Engineering, Peking University, Beijing, China \\ ${ }^{2}$ Department of Civil and Environmental Engineering, Faculty of Science and Technology, \\ University of Macau, Taipa, Macau SAR, China
}

Correspondence: Qi Chen (qichenpku@pku.edu.cn) and Yong Jie Li (yongjieli@um.edu.mo)

Received: 7 March 2021 - Discussion started: 11 March 2021

Revised: 26 June 2021 - Accepted: 29 June 2021 - Published: 11 August 2021

\begin{abstract}
Oxidation of aromatic volatile organic compounds (VOCs) leads to the formation of tropospheric ozone and secondary organic aerosol, for which gaseous oxygenated products are important intermediates. We show, herein, the experimental results of highly oxygenated organic molecules (HOMs) produced by the oxidation of benzene and toluene in a wide range of $\mathrm{OH}$ exposure and $\mathrm{NO}_{x}$ conditions. The results suggest that multigeneration $\mathrm{OH}$ oxidation plays an important role in the product distribution, which likely proceeds more preferably via $\mathrm{H}$ subtraction than $\mathrm{OH}$ addition for early generation products from light aromatics. More oxygenated products present in our study than in previous flow tube studies, highlighting the impact of experimental conditions on product distributions. The formation of dimeric products, however, was suppressed and might be unfavorable under conditions of high $\mathrm{OH}$ exposure and low $\mathrm{NO}_{x}$ in toluene oxidation. Under high- $\mathrm{NO}_{x}$ conditions, nitrogen-containing multifunctional products are formed, while the formation of other HOMs is suppressed. Products containing two nitrogen atoms become more important as the $\mathrm{NO}_{x}$ level increases, and the concentrations of these compounds depend significantly on $\mathrm{NO}_{2}$. The highly oxygenated nitrogen-containing products might be peroxyacyl nitrates, implying a prolonged effective lifetime of $\mathrm{RO}_{2}$ that facilitates regional pollution. Our results call for further investigation on the roles of high$\mathrm{NO}_{2}$ conditions in the oxidation of aromatic VOCs.
\end{abstract}

\section{Introduction}

Atmospheric oxidation of volatile organic compounds (VOCs) are crucial in the formation of tropospheric ozone $\left(\mathrm{O}_{3}\right)$ and secondary organic aerosol (SOA; Calvert et al., 2015; Seinfeld and Pandis, 2016). Enormous studies have been conducted for the $\mathrm{O}_{3}$ formation potentials and SOA yields of light aromatic VOCs such as benzene and toluene (Calvert et al., 2002; Atkinson and Arey, 2003; Ziemann and Atkinson, 2012). The peroxy radicals (either $\mathrm{RO}_{2}$ or $\mathrm{HO}_{2}$ ) that are generated from the oxidation process convert $\mathrm{NO}$ to $\mathrm{NO}_{2}$. Ground-state oxygen atoms $\mathrm{O}\left({ }^{3} \mathrm{P}\right)$ are produced through the photolysis of $\mathrm{NO}_{2}$, and the reaction between the $\mathrm{O}\left({ }^{3} \mathrm{P}\right)$ and $\mathrm{O}_{2}$ is the main source of tropospheric $\mathrm{O}_{3}$ (Calvert et al., 2015). The oxygenated organic products, on the other hand, may form SOA through either nucleation or condensation with various mass yields, depending on the structure of the precursors and the $\mathrm{NO}_{x}\left(=\mathrm{NO}+\mathrm{NO}_{2}\right)$ level $(\mathrm{Ng}$ et al., 2007; Li et al., 2016). Therefore, for both $\mathrm{O}_{3}$ and SOA formation via VOC oxidation, $\mathrm{NO}_{x}$ plays a critical role (Atkinson, 2000; Sato et al., 2012; Tsiligiannis et al., 2019; Garmash et al., 2020).

$\mathrm{OH}$-initiated oxidation of light aromatics occurs mainly via $\mathrm{OH}$ addition, with about $90 \%$ of preference (Calvert et al., 2002; Wu et al., 2014; Schwantes et al., 2017). As described in Sect. S1 in the Supplement, the formation of bicyclic peroxy radicals (BPRs) is central to aromatic oxidation in the absence of $\mathrm{NO}_{x}$. Significant fractions of the oxidation (e.g., 0.35 for benzene and 0.65 for toluene) may lead 
to the formation of BPRs (Scheme S1 in the Supplement; Birdsall et al., 2010), followed by further reactions to form highly oxygenated organic molecules (HOMs; Crounse et al., 2013; Ehn et al., 2014; Berndt et al., 2016; Bianchi et al., 2019). The fate of the BPRs has been recently investigated by using a time-of-flight chemical ionization mass spectrometer (TOF-CIMS), which is suitable for measuring HOMs. The TOF-CIMS measurements show that major products for the reactions between BPRs and $\mathrm{HO}_{2} / \mathrm{RO}_{2}$ in the absence of $\mathrm{NO}_{x}$ include carbonyls, alcohols, hydroperoxides, dimers, and alkoxy (RO) radicals (Birdsall et al., 2010; Wang et al., 2017; Molteni et al., 2018; Zaytsev et al., 2019b; Garmash et al., 2020). The BPR-derived products that still possess the bicyclic skeleton are considered as being the major ringretaining products from the oxidation of light aromatics (Zaytsev et al., 2019b). The decomposition of RO radicals may lead to fragmented products such as di-carbonyls and epoxides (Yu and Jeffries, 1997; Yu et al., 1997; Arey et al., 2009; Zaytsev et al., 2019b). The formation of HOMs may involve multistep auto-oxidation and multigeneration $\mathrm{OH}$ reaction (Zaytsev et al., 2019b; Garmash et al., 2020; Y. Wang et al., 2020). Yet, it is still unclear whether the formation of HOMs is controlled by multistep auto-oxidation or multigeneration $\mathrm{OH}$ oxidation.

Conditions of flow tube or smog chamber experiments have covered various conditions of $\mathrm{OH}$ concentrations $\left(10^{4}\right.$ to $10^{11} \mathrm{molcm}^{-3}$ ) and residence times $(10 \mathrm{~s}$ to $1 \mathrm{~h}$; Wang et al., 2017; Molteni et al., 2018; Garmash et al., 2020). Extrapolation of these results to tropospheric conditions requires further investigations under a wide range of $\mathrm{NO}_{x}$ levels. $\mathrm{NO}_{x}$ are rich in urban environments and compete with $\mathrm{HO}_{2}$ and $\mathrm{RO}_{2}$ for the termination of $\mathrm{RO}_{2}$ radicals (Calvert et al., 2002; Seinfeld and Pandis, 2016). Early studies show a strong dependence of SOA mass yields on $\mathrm{NO}_{x}$, owing to the formation of more volatile products through the termination of $\mathrm{RO}_{2}$ by $\mathrm{NO}$ ( $\mathrm{Ng}$ et al., 2007; Sato et al., 2012). There are also a few recent studies on the gaseous oxygenated products from aromatic oxidation in the presence of $\mathrm{NO}_{x}$ (Tsiligiannis et al., 2019; Garmash et al., 2020; Y. Wang et al., 2020). Garmash et al. (2020) found that nitrated phenols (NPs) contribute significantly to the gaseous nitrogen-containing HOMs produced by the benzene oxidation in the presence of $\mathrm{NO}_{x}$. Tsiligiannis et al. (2019) show the prevalent formation of organic nitrates (ONs) from 1,3,5-trimethylbenzene (TMB) oxidation, especially for atmospherically relevant $\left[\mathrm{NO}_{x}\right]:[\mathrm{VOC}]$ ratios greater than 1 . In addition to ONs, Y. Wang et al. (2020) show the elevated formation of dinitrates from the oxidation of TMB isomers in the presence of $\mathrm{NO}_{x}$. In general, the formation of these nitrogen-containing products suppresses the formation of other HOMs (Tsiligiannis et al., 2019; Garmash et al., 2020; Y. Wang et al., 2020). However, the dependence of product distributions on $\mathrm{NO}_{x}$ conditions (e.g., $\left[\mathrm{NO}_{x}\right]:[\mathrm{VOC}]$ or $\left[\mathrm{NO}_{2}\right]:[\mathrm{NO}]$ ratios) remains largely unclear.
In this study, we investigate the production of gaseous HOMs from the OH-initiated oxidation of benzene and toluene in an oxidation flow reactor (OFR) by using nitrate adduct TOF-CIMS ( $\mathrm{NO}_{3}^{-}$-TOF-CIMS). A wide range of $\mathrm{OH}$ exposure and $\mathrm{NO}_{x}$ conditions are studied. Distributions and molar yields of key products are investigated. Kinetic analysis helps in inferring the possible formulas of nitrogencontaining HOMs.

\section{Experimental section}

\subsection{Oxidation flow reactor}

The oxidation experiments are conducted in a 13.3 L Aerodyne Research Inc. potential aerosol mass (PAM) OFR reactor. The schematic of the experimental setup and the example experimental sequence are shown in Figs. S1 and S2 in the Supplement, respectively. The OFR was operated in two continuous flow modes named OFR254-5 and OFR254-5-iN $2 \mathrm{O}$ (Lambe et al., 2017; Peng et al., 2018). For the OFR254-5 mode, the inside UV lamps emit photons at $254 \mathrm{~nm}$ to generate $\mathrm{OH}$ radicals in the reactor via the reaction of $\mathrm{O}\left({ }^{1} \mathrm{D}\right)+$ $\mathrm{H}_{2} \mathrm{O} \rightarrow 2 \mathrm{OH}$. An outside UV lamp produces $\mathrm{O}_{3}$ and leads to about $5 \mathrm{ppm}$ (parts per million) of $\mathrm{O}_{3}$ in the OFR. For the OFR254-5- $\mathrm{iN}_{2} \mathrm{O}$ mode, $\mathrm{N}_{2} \mathrm{O}(99.5 \%)$ is injected into the OFR to achieve $\mathrm{N}_{2} \mathrm{O}$ mixing ratios of $1.1 \%$ (OFR2545-iN $\mathrm{i}_{2} \mathrm{O} 1.1$ ) and $4.4 \%$ (OFR254-5- $\left.\mathrm{iN}_{2} \mathrm{O} 4.4\right)$. $\mathrm{NO}$ and $\mathrm{NO}_{2}$ are then formed by the reaction $\mathrm{O}\left({ }^{1} \mathrm{D}\right)+\mathrm{N}_{2} \mathrm{O} \rightarrow 2 \mathrm{NO}$, followed by the reaction $\mathrm{NO}+\mathrm{O}_{3} \rightarrow \mathrm{NO}_{2}+\mathrm{O}_{2}$ (Lambe et al., 2017). The conditions for OFR $254-5$ are considered as being low- $\mathrm{NO}_{x}$, whereas the latter are high- $\mathrm{NO}_{x}$. Under each of these three sets of experiments, $\mathrm{OH}$ exposure and $\mathrm{NO}_{x}$ levels were varied by ramping the voltage of the UV lamps in the OFR. The total flow rate was about $8.4 \mathrm{~L} \mathrm{~min}^{-1}$, resulting in a mean residence time of $95 \mathrm{~s}$ in the OFR. Relative humidity (RH) in the OFR was about $20 \%$ to $55 \%$ at $25 \pm 2{ }^{\circ} \mathrm{C}$, corresponding to $\mathrm{H}_{2} \mathrm{O}$ mixing ratios of about $0.7 \%$ to $1.5 \%$. Details about the experimental setup are provided in Sect. S2 in the Supplement.

In total, 28 experiments were conducted for initial mixing ratios of $110 \mathrm{ppb}$ (parts per billion) benzene and $50 \mathrm{ppb}$ toluene. Table S1 in the Supplement lists the experimental conditions and the measured and derived quantities for all experiments. The concentrations of reactive species such as $\mathrm{OH}, \mathrm{HO}_{2}, \mathrm{NO}$, and $\mathrm{NO}_{2}$ were estimated by an OFR-based photochemical box model (PAMchem; Lambe et al., 2017). The box model simulations are described in detail in Sect. S2, for which calibration experiments with $\mathrm{SO}_{2}$ were conducted to constrain the actinic flux at $254 \mathrm{~nm}$ (Fig. S3 in the Supplement). Briefly, the model suggests $\mathrm{OH}$ exposure of about $1.1 \times 10^{11}$ to $2.5 \times 10^{12} \mathrm{~mol} \mathrm{~cm}^{-3} \mathrm{~s}$ for our experiments, corresponding to equivalent photochemical age of 0.8 to $19.3 \mathrm{~d}$, with a mean $\mathrm{OH}$ concentration of $1.5 \times 10^{6} \mathrm{~mol} \mathrm{~cm}^{-3}$. For high $\mathrm{NO}_{x}$ experiments, the OFR exit $\mathrm{NO}$ and $\mathrm{NO}_{2}$ concentra- 
tions were 0.2 to $5.1 \mathrm{ppb}$ and 15.8 to $231.4 \mathrm{ppb}$, respectively, leading to $\left[\mathrm{NO}_{x}\right]$ : $[\mathrm{VOC}]$ ratios of 0.2 to 2.2 for benzene and 0.4 to 4.7 for toluene. The OFR-based photochemical box simulations show that the aromatic oxidation reactions in our experimental conditions were dominated by $\mathrm{OH}$ rather than $\mathrm{O}_{3}$ (Lambe et al., 2011; Peng et al., 2016). Similar to other OFR studies, we think the reaction rates of $\mathrm{O}_{3}$ with oxidation products that contain double bounds are likely slower compared to that of OH (Molteni et al., 2018; Y. Wang et al., 2020). The $\mathrm{NO}_{3}$ concentrations in the OFR range from 0.01 to $0.09 \mathrm{ppb}$. The general reaction rate of $\mathrm{RO}_{2}$ with $\mathrm{OH}$ is 1 order of magnitude greater than that with $\mathrm{NO}_{3}$ under our experimental conditions (Jenkin et al., 2019). For such rates, the $\mathrm{NO}_{3}$ reactions with $\mathrm{HOM}$ products might be minor. The $\mathrm{NO}_{3}$ oxidation of phenols, however, may contribute efficiently to the formation of nitrated phenols in the OFR because of the high branching ratio.

\subsection{Chemical characterization}

HOMs were characterized by an Aerodyne Research Inc. $\mathrm{NO}_{3}^{-}$-TOF-CIMS. Details about the instrument operation and data analysis are described elsewhere (Cheng et al., 2021). Briefly, mass calibration was performed on the reagent ions and selected Teflon-related ions, which covers the $m / z$ range of 62 to 676 , with mass accuracies of less than $10 \mathrm{ppm}$. The non-production ions were identified by positive matrix factorization (PMF) analysis and were removed from the analysis (Fig. S4 in the Supplement). The $\mathrm{HNO}_{3} \mathrm{NO}_{3}^{-}$ adduct ions were identified by the signal correlations between the $\mathrm{NO}_{3}^{-}$adduct and $\mathrm{HNO}_{3} \mathrm{NO}_{3}^{-}$adduct ions and were removed from the analysis (Fig. S5 in the Supplement). Only $\mathrm{NO}_{3}^{-}$adduct ions are presented herein. The background signals of individual ions were determined on the basis of the measurements made without the injection of VOCs (Fig. S2). Because of the lack of standards, we applied the calibration factor of 4-nitrophenol (i.e., $0.0020 \mathrm{ncps} \mathrm{ppt}^{-1}$ (normalized counts per second per parts per trillion) or $1.66 \times$ $10^{10} \mathrm{~mol} \mathrm{~cm}^{-3}$ ) to HOMs, which is similar to the commonly used calibration factors of $\mathrm{H}_{2} \mathrm{SO}_{4}$ (i.e., $1.62 \times 10^{10} \mathrm{~mol} \mathrm{~cm}^{-3}$ for our instrument herein and $1.89 \times 10^{10} \mathrm{~mol} \mathrm{~cm}^{-3}$ reported by Jokinen et al., 2012) and perfluoroheptanoic acid (i.e., $1.6 \times 10^{10} \mathrm{~mol} \mathrm{~cm}^{-3}$ as reported by Ehn et al., 2014). All calibration factors are corrected by wall losses. Ehn et al. (2014) reported a $\pm 50 \%$ of uncertainty. For our experiments, we estimate an uncertainty of $42 \%$ on the basis of nitrated phenol calibrations (Cheng et al., 2021). In some experiments, the VOC precursors and less-oxygenated gaseous products were monitored by an IONICON proton transfer reactionquadrupole interface time-of-flight mass spectrometer (PTRQiTOF). The instrument operation and data analysis have been described previously (Huang et al., 2019). The measurements have a total uncertainty of about $21 \%$. Particle size distributions were measured by a scanning mobility particle sizer (SMPS; TSI Incorporated; model no. 3938). The SOA mass concentrations are measured by an Aerodyne long timeof-flight soot particle aerosol mass spectrometer (LTOF-SPAMS) for the calculation of condensation sink in wall loss corrections of HOMs (Zheng et al., 2020).

\section{Results and discussion}

\subsection{Product categories}

Figure 1 shows the mass spectra of gaseous oxygenated products produced by benzene and toluene oxidation in typical low- and high- $\mathrm{NO}_{x}$ experiments. The fitted ion peaks are categorized into fragmented products, open-shell monomeric products, closed-shell monomeric products, and dimeric products, as well as nitrogen-containing products when $\mathrm{NO}_{x}$ is present. The proposed product categories are based on traditional understanding and recent mechanistic developments of aromatic oxidation (Wang et al., 2017; Mentel et al., 2015; Molteni et al., 2019). In benzene and toluene $\left(\mathrm{C}_{x} \mathrm{H}_{y}\right)$ oxidation by $\mathrm{OH}$ radicals, the addition of $\mathrm{OH}$ and two $\mathrm{O}_{2}$ molecules leads to the formation of $\mathrm{BPR}_{x} \mathrm{H}_{y+1} \mathrm{O}_{5}$, which increase the molecular composition by one $\mathrm{H}$ atom and five oxygen atoms. The BPR $\mathrm{C}_{x} \mathrm{H}_{y+1} \mathrm{O}_{5}$ can undergo further autoxidation and forms radicals with the formula $\mathrm{C}_{x} \mathrm{H}_{y+1} \mathrm{O}_{7}$. Autoxidation of $\mathrm{RO}_{2}$ radicals involves intramolecular hydrogen shifts to the peroxide group from other carbon atoms and the subsequent addition of oxygen to the produced carboncentered radicals. The $\mathrm{H}$ shift itself does not modify the molecular composition, but $\mathrm{O}_{2}$ addition increases the oxygen content by an even number. Besides, BPR $\mathrm{C}_{x} \mathrm{H}_{y+1} \mathrm{O}_{5}$ can form termination products of carbonyls $\left(\mathrm{C}_{x} \mathrm{H}_{y} \mathrm{O}_{4}\right)$, alcohols $\left(\mathrm{C}_{x} \mathrm{H}_{y+2} \mathrm{O}_{4}\right)$, hydroperoxides $\left(\mathrm{C}_{x} \mathrm{H}_{y+2} \mathrm{O}_{5}\right)$, dimers, and nitrogen-containing compounds. Notably, product distributions are affected by the numbers of the generation of the auto-oxidation pathway and the $\mathrm{H}$ shift reaction rates. Some product formulae may involve multiple pathways, as discussed later in Sect. 3.2, for which additional information (e.g., collision induced dissociation experiments) may be helpful to further explore possible structures of the HOM molecules (Zaytsev et al., 2019a).

Tables S2-S3 in the Supplement list the corresponding peak lists and relative signal contributions of major products in each category for the low- and high- $\mathrm{NO}_{x}$ experiments in Fig. 1. The fragmented products are the most abundant category under low- $\mathrm{NO}_{x}$ conditions. They have carbon numbers less than their precursors, possibly indicating ring opening or scission, presumably from RO radicals (Zaytsev et al., 2019b). In addition, fragmented products can be formed through $\mathrm{CO}$ elimination from an acyl radical (Rissanen et al., 2014), splitting $\mathrm{CO}_{2}$ from an RO radical (Garmash et al., 2020), or dealkylation (Birdsall and Elrod, 2011). In this study, $\mathrm{C}_{2} \mathrm{H}_{4} \mathrm{O}_{4}$ shows the highest signal intensity in the fragmented category under low- $\mathrm{NO}_{x}$ conditions. $\mathrm{C}_{4} \mathrm{H}_{4} \mathrm{O}_{5}$ and $\mathrm{C}_{5} \mathrm{H}_{4} \mathrm{O}_{6}$ are the other two abundant common products 


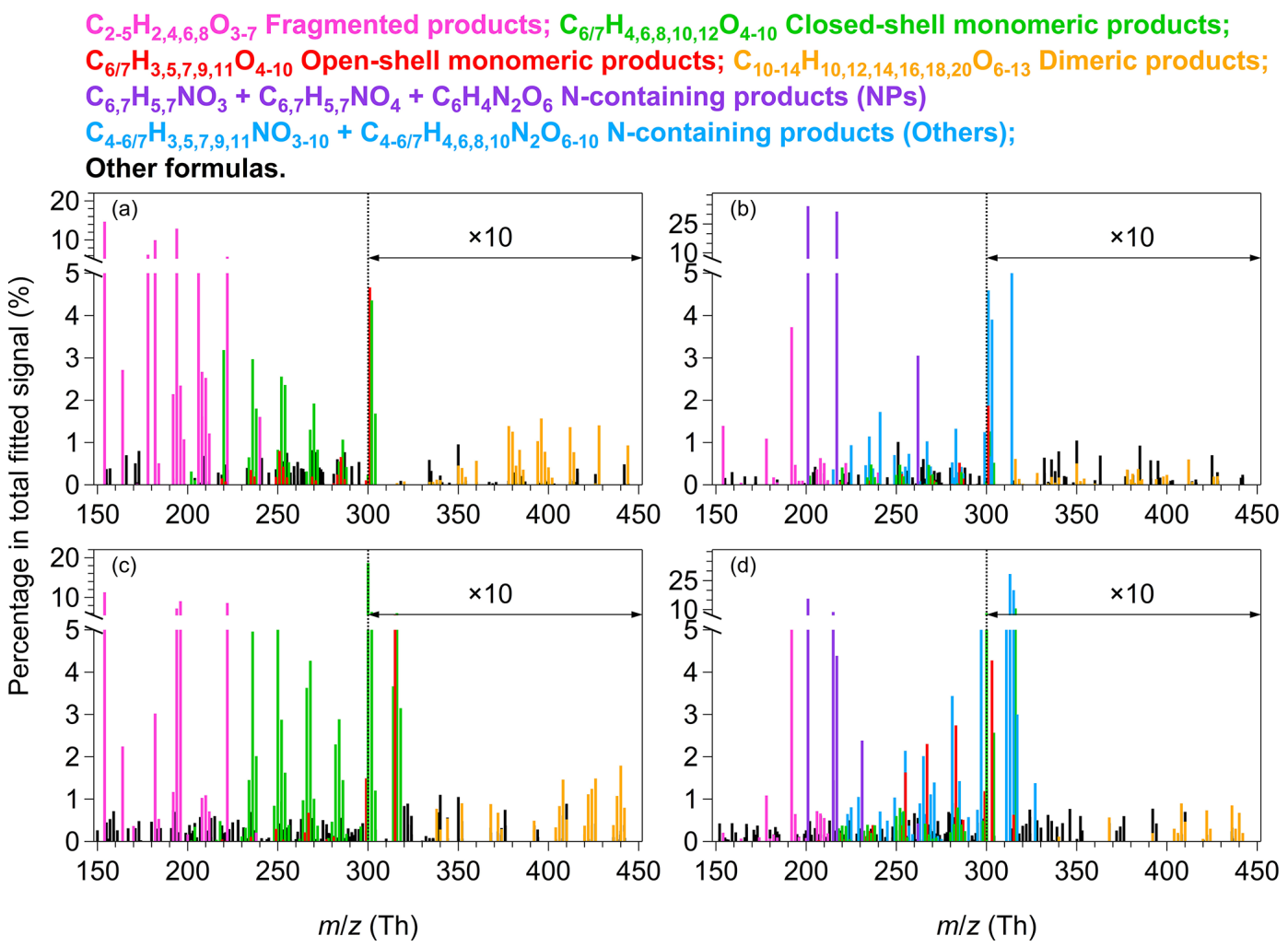

Figure 1. Mass spectra of HOM products measured by the $\mathrm{NO}_{3}^{-}$-TOF-CIMS for experiment nos. 2, 11, 16, and 26 in Table S1. (a) Benzene

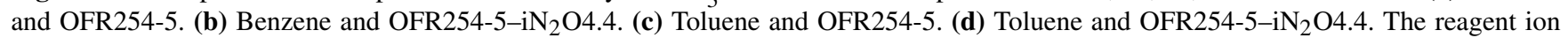
$\mathrm{NO}_{3}^{-}$is omitted from the molecular formulas, whereas the $m / z$ values refer to the mass-to-charge ratios of the fitted ions, with $\mathrm{NO}_{3}^{-}$. The relative intensities of ions having $m / z \geq 300$ are multiplied by 10 .

in this category. Under high- $\mathrm{NO}_{x}$ conditions, $\mathrm{C}_{4} \mathrm{H}_{2} \mathrm{O}_{5}$ is the most abundant common product for benzene and toluene oxidation. Many of the fragmented products have been detected in SOA (Gallimore et al., 2011; Gowda and Kawamura, 2018).

The ring-retaining HOM monomers may have even (closed shell) or odd (open shell) hydrogen numbers (Molteni et al., 2018; Zaytsev et al., 2019b; Garmash et al., 2020). With relatively large carbon numbers, the $\mathrm{RO}_{2}$ radicals generally have lifetimes of seconds that are much longer than the RO radicals of $<10^{-4} \mathrm{~s}$ (Orlando et al., 2003; Seinfeld and Pandis, 2016; Zhao et al., 2018). The open-shell monomeric products observed by the $\mathrm{NO}_{3}^{-}$-TOF-CIMS in this study are, therefore, more likely $\mathrm{RO}_{2}$ radicals rather than $\mathrm{RO}$ radicals. Under low- $\mathrm{NO}_{x}$ conditions, the BPRs have relatively low signal intensities $(0.1 \%)$. Products that are presumably formed by further auto-oxidation of BPRs, such as $\mathrm{C}_{6} \mathrm{H}_{7} \mathrm{O}_{7}$ and $\mathrm{C}_{6} \mathrm{H}_{7} \mathrm{O}_{9}$ for benzene (or $\mathrm{C}_{7} \mathrm{H}_{9} \mathrm{O}_{7}$ and $\mathrm{C}_{7} \mathrm{H}_{9} \mathrm{O}_{9}$ for toluene), have much greater signal intensities compared with the BPRs, especially for the $\mathrm{O}_{9}$ products. Other openshell monomeric products with two fewer hydrogen atoms (e.g., $\mathrm{H}_{5}$ for benzene and $\mathrm{H}_{7}$ for toluene) or with an even number of oxygen atoms (e.g., $\mathrm{O}_{6}$ or $\mathrm{O}_{10}$ ) are also present.
Under high- $\mathrm{NO}_{x}$ conditions, the main open-shell monomers are the $\mathrm{O}_{9}$ products, which is similar to the low- $\mathrm{NO}_{x}$ case.

Among the closed-shell monomeric products produced by benzene oxidation, $\mathrm{C}_{6} \mathrm{H}_{6} \mathrm{O}_{5-10}$ and $\mathrm{C}_{6} \mathrm{H}_{8} \mathrm{O}_{5-10}$ with one oxygen atom apart show relatively high signal intensities, and $\mathrm{C}_{6} \mathrm{H}_{6} \mathrm{O}_{5}$ and $\mathrm{C}_{6} \mathrm{H}_{6} \mathrm{O}_{6}$ are the most abundant ones. $\mathrm{C}_{6} \mathrm{H}_{6} \mathrm{O}_{5}$ and $\mathrm{C}_{6} \mathrm{H}_{6} \mathrm{O}_{6}$ might be carbonyl products from the termination of $\mathrm{C}_{6} \mathrm{H}_{7} \mathrm{O}_{6}$ and $\mathrm{C}_{6} \mathrm{H}_{7} \mathrm{O}_{7}$ by $\mathrm{HO}_{2}$ or $\mathrm{RO}_{2}$ (Zaytsev et al., 2019b; Garmash et al., 2020). $\mathrm{C}_{6} \mathrm{H}_{7} \mathrm{O}_{6}$ is probably formed by the ring breakage of the bicyclic alkoxy radical followed by the 1,5 aldehydic alkoxy $\mathrm{H}$ shift reactions $\mathrm{Xu}$ et al., 2020) which involve the RO pathway, as described in detail in Sect. S3 of the Supplement. For other products formed by the termination reactions of BPR with $\mathrm{HO}_{2}$ or $\mathrm{RO}_{2}$, bicyclic hydroperoxide $\left(\mathrm{C}_{6} \mathrm{H}_{8} \mathrm{O}_{5}\right)$, carbonyl $\left(\mathrm{C}_{6} \mathrm{H}_{6} \mathrm{O}_{4}\right)$, and alcohol $\left(\mathrm{C}_{6} \mathrm{H}_{8} \mathrm{O}_{4}\right)$ have relatively small signals, whereas the products that may involve two or three steps of autooxidation (e.g., $\mathrm{C}_{6} \mathrm{H}_{8} \mathrm{O}_{7}$ and $\mathrm{C}_{6} \mathrm{H}_{8} \mathrm{O}_{9}$ ) have greater signal intensities. BPRs (i.e., $\mathrm{C}_{6} \mathrm{H}_{7} \mathrm{O}_{5}$ from benzene oxidation and $\mathrm{C}_{7} \mathrm{H}_{9} \mathrm{O}_{5}$ from toluene oxidation) can undergo unimolecular isomerization reactions to form more oxidized peroxy radicals, which compete with bimolecular reactions (Wang et al., 2017). The relative greater signal intensities of ring-retaining $\mathrm{O}_{7}$ or $\mathrm{O}_{9} \mathrm{HOM}$ monomers compared with $\mathrm{O}_{<6}$ ones sug- 
gest that the termination of $\mathrm{RO}_{2}$ by $\mathrm{HO}_{2}$ and the phenol oxidation pathway are perhaps relatively less important than the auto-oxidation pathway under experimental conditions herein (Calvert et al., 2002; Schwantes et al., 2017; Garmash et al., 2020). Similarly, for toluene oxidation, the bicyclic hydroperoxide $\left(\mathrm{C}_{7} \mathrm{H}_{10} \mathrm{O}_{5}\right)$ shows lower signals than $\mathrm{C}_{7} \mathrm{H}_{10} \mathrm{O}_{7}$ and $\mathrm{C}_{7} \mathrm{H}_{10} \mathrm{O}_{9}$ that may be associated with multiple steps of auto-oxidation. $\mathrm{C}_{7} \mathrm{H}_{8} \mathrm{O}_{6}$ and $\mathrm{C}_{7} \mathrm{H}_{8} \mathrm{O}_{7}$ are the main closedshell monomers that might be carbonyls that are produced by the termination of $\mathrm{C}_{7} \mathrm{H}_{9} \mathrm{O}_{7}$ and $\mathrm{C}_{7} \mathrm{H}_{9} \mathrm{O}_{8}$ by $\mathrm{HO}_{2}$ or $\mathrm{RO}_{2}$, respectively. The formation of $\mathrm{C}_{7} \mathrm{H}_{8} \mathrm{O}_{7}$ may also be explained by the RO pathway, similar to $\mathrm{C}_{6} \mathrm{H}_{6} \mathrm{O}_{5}$ (Sect. S3). The $\mathrm{RO}$ pathway, if it occurs, may potentially lead to various products with significant signals, which remains largely overlooked in studies of aromatic oxidation (Xu et al., 2020).

The other two categories are dimeric and nitrogencontaining products. In our study, the ion intensities of dimeric products with odd hydrogen atoms are low. We, therefore, focus on the dimeric products with even hydrogen atoms. Under low- $\mathrm{NO}_{x}$ conditions, dimeric products with 8-14 even oxygen atoms are clearly present. $\mathrm{C}_{12} \mathrm{H}_{14} \mathrm{O}_{8}$ and $\mathrm{C}_{14} \mathrm{H}_{18} \mathrm{O}_{8}$ are perhaps formed via self-reactions of the BPRs for benzene and toluene, respectively. The distribution of dimeric products is in line with the monomeric openshell and closed-shell products. We observe a number of dimeric products with odd oxygen numbers that are perhaps produced by cross-reactions of odd and even oxygen $\mathrm{RO}_{2}$ (Molteni et al., 2018; Garmash et al., 2020). The presence of $\mathrm{NO}_{x}$ results in the formation of nitrogen-containing products with one or two nitrogen atoms, and the signal abundances of all other oxygenated products are much lower than the case of low- $\mathrm{NO}_{x}$ experiments. Such a suppression has been reported previously (Tsiligiannis et al., 2019; Garmash et al., 2020; Y. Wang et al., 2020; Mehra et al., 2020). The nitrogen-containing products are expected to be organic nitrates or nitrated phenols. For benzene oxidation, $\mathrm{C}_{6} \mathrm{H}_{5} \mathrm{NO}_{3}$, $\mathrm{C}_{6} \mathrm{H}_{5} \mathrm{NO}_{4}$, and $\mathrm{C}_{6} \mathrm{H}_{4} \mathrm{~N}_{2} \mathrm{O}_{6}$ are the most abundant, which are plausibly nitrophenol, nitrocatechol, and dinitrocatechol, respectively. For toluene, $\mathrm{C}_{6} \mathrm{H}_{5} \mathrm{NO}_{3}$ (nitrophenol), $\mathrm{C}_{6} \mathrm{H}_{5} \mathrm{NO}_{4}$ (nitrocatechol), $\mathrm{C}_{7} \mathrm{H}_{7} \mathrm{NO}_{3}$ (methylnitrophenol), and $\mathrm{C}_{7} \mathrm{H}_{7} \mathrm{NO}_{4}$ (methylnitrocatechol) are the main tentatively assigned nitrated phenols. Significant secondary production of these compounds from aromatic oxidation have been observed in urban Beijing (Cheng et al., 2021). Other products, such as $\mathrm{C}_{6} \mathrm{H}_{7} \mathrm{NO}_{8}, \mathrm{C}_{6} \mathrm{H}_{7} \mathrm{NO}_{9}$, and $\mathrm{C}_{7} \mathrm{H}_{9} \mathrm{NO}_{8}$, are most likely organic (peroxy) nitrates. Schemes $\mathrm{S} 2$ and S3 in the Supplement give examples of the proposed formation mechanisms for nitrogen-containing products and multistep auto-oxidation products, starting from the BPR of $\mathrm{C}_{7} \mathrm{H}_{9} \mathrm{O}_{5}$ (Sect. S1).

\subsection{Low-NO ${ }_{x}$ conditions}

\section{Product distribution}

The products that we observed herein (Tables S2-S3) are generally in agreement with those found in previous low$\mathrm{NO}_{x}$ studies (Schwantes et al., 2017; Molteni et al., 2018; Zaytsev et al., 2019b; Mehra et al., 2020; Garmash et al., 2020). Differences exist in the relative abundance of species with different oxygen contents within each product category (Molteni et al., 2018; Garmash et al., 2020). Table S4 in the Supplement lists the experimental conditions and relative signal intensities of some major oxygenated products formed by benzene oxidation. Molteni et al. (2018) observes a predominant production of $\mathrm{C}_{6} \mathrm{H}_{8} \mathrm{O}_{5}$ (plausibly hydroperoxides) and $\mathrm{C}_{12} \mathrm{H}_{14} \mathrm{O}_{8}$. Garmash et al. (2020) shows relatively high signals of $\mathrm{C}_{6} \mathrm{H}_{8} \mathrm{O}_{9}$ and $\mathrm{C}_{12} \mathrm{H}_{14} \mathrm{O}_{8}$ in the flow tube experiments, whereas the chamber study and our study both show relatively high signals of $\mathrm{C}_{6} \mathrm{H}_{8} \mathrm{O}_{7}$ and $\mathrm{C}_{6} \mathrm{H}_{8} \mathrm{O}_{9}$ and lower signals of dimeric products. Moreover, the signal intensities of $\mathrm{RO}_{2}$ (e.g., $\mathrm{C}_{6} \mathrm{H}_{7} \mathrm{O}_{5}$ and $\mathrm{C}_{6} \mathrm{H}_{7} \mathrm{O}_{7}$ ) are greater in our study than in other studies. Both experimental conditions and instrument detection are factors that may affect the product distribution. For example, a longer residence time might promote multistep auto-oxidation. For auto-oxidation, the $\mathrm{H}$ shift has rate constants of about $10^{-3}$ to $1 \mathrm{~s}^{-1}$ and is likely the rate-determining step under atmospheric conditions, with reaction times of 1 to $10^{3} \mathrm{~s}$ that are much longer than the subsequent $\mathrm{O}_{2}$ addition of microseconds (hereafter $\mu$ s) (Orlando et al., 2003; Bianchi et al., 2019). Garmash et al. (2020) indicated that fewer auto-oxidation steps would be expected in flow tube experiments. The flow tube study herein has a relatively longer residence time than others, which is consistent with relatively more abundant $\mathrm{O}_{7}$ and $\mathrm{O}_{9}$ products. Ambient environments have much lower $\mathrm{OH}$ concentrations but longer residence times, depending on meteorological conditions, which may suggest more oxygenated products from multisteps of auto-oxidation. Alternatively, the differences in $\mathrm{HO}_{2}$ and $\mathrm{RO}_{2}$ concentrations among different studies that remain unclear might affect the extent of auto-oxidation. For detection, the instrument efficiency might be different for HOMs with different clustering capabilities (e.g., numbers of functional groups as hydrogen bond donors; Hyttinen et al., 2015). Tuning might affect the transmission of product ions in different $m / z$ ranges or affect the efficiency of dimer clustering (Heinritzi et al., 2016; Brophy and Farmer, 2015).

\section{Effects of $\mathrm{OH}$ exposure}

As shown in Fig. 2a, the concentrations of fragmented, monomeric closed-shell and open-shell and dimeric products formed by benzene oxidation increase with increasing $\mathrm{OH}$ exposure that corresponds to 2.4 to $16.1 \mathrm{~d}$ of atmospheric equivalent photochemical age. Elevated concentrations of monomeric open-shell products (e.g., $\mathrm{RO}_{2}$ ) and $\mathrm{HO}_{2}$ are ex- 


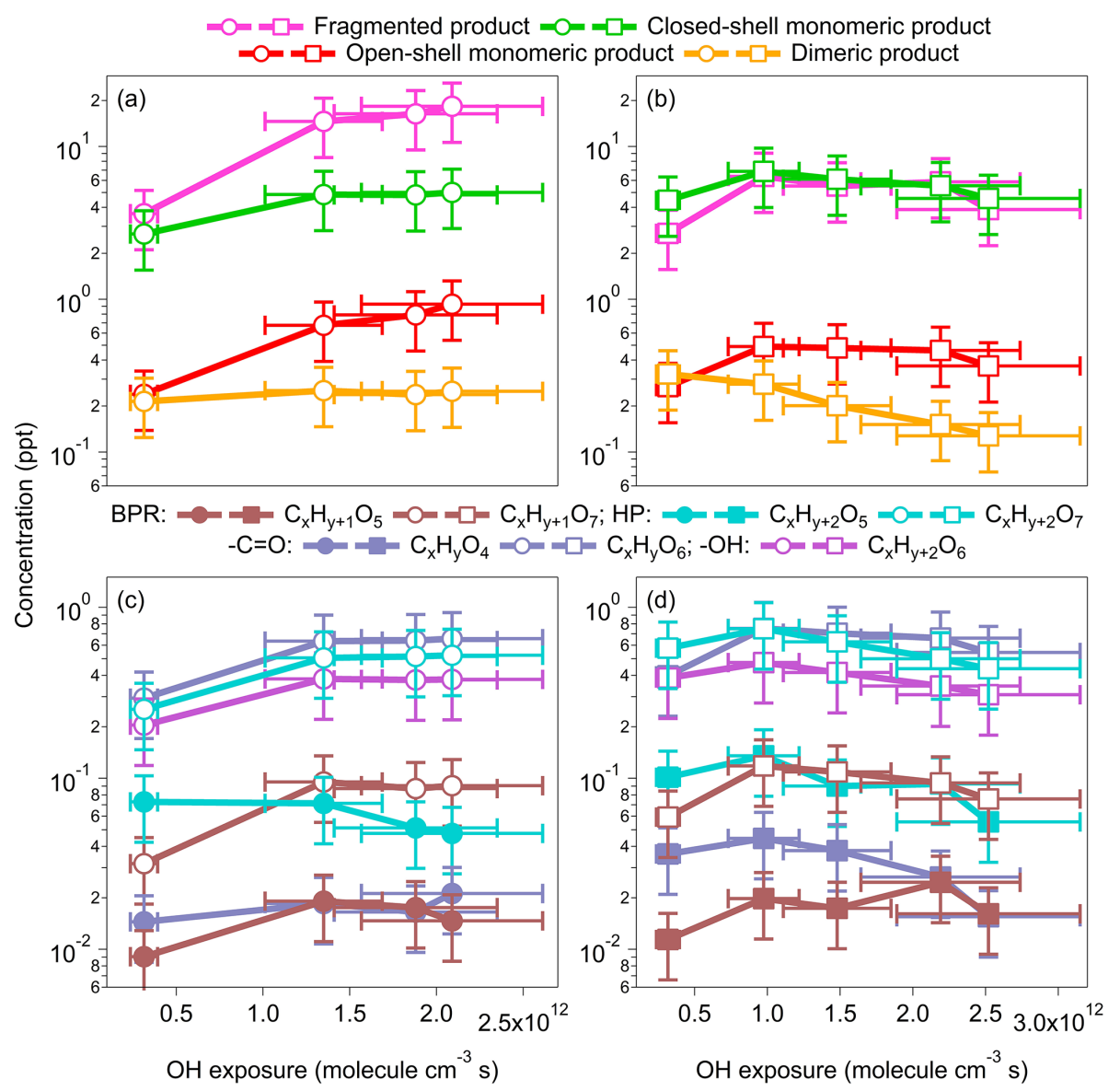

Figure 2. Concentrations of fragmented, monomeric closed-shell, open-shell, and dimeric products formed by benzene and toluene oxidation under low- $\mathrm{NO}_{x}$ conditions (OFR254-5) at various $\mathrm{OH}$ exposures. For the benzene oxidation, both $x$ and $y$ are 6 . For the toluene oxidation, $x$ is 7 , and $y$ is 8 . Note: $\mathrm{BPR}$ - bicyclic peroxy radical; $\mathrm{HP}$ - hydroperoxide; $-\mathrm{C}=\mathrm{O}-$ carbonyl; $-\mathrm{OH}-$ alcohol.

pected for greater $\mathrm{OH}$ exposure, leading to enhanced production of the monomeric closed-shell and dimeric products through the $\mathrm{RO}_{2}+\mathrm{HO}_{2}$ and $\mathrm{RO}_{2}+\mathrm{RO}_{2}$ reactions. These processes may be limited by the availability of $\mathrm{RO}_{2}(<0.9 \mathrm{ppt}$ (parts per trillion) in our study) rather than that of $\mathrm{HO}_{2}$ (0.5-2.4 ppb; Table S1). Consistently, the concentrations of dimeric products are much lower than those of monomeric closed-shell products. For toluene oxidation, the dependence of the product formation on $\mathrm{OH}$ exposure is less significant than that for benzene (Fig. 2b). The concentrations of fragmented, monomeric closed-shell and open-shell products first increase and then slightly decrease with the increasing $\mathrm{OH}$ exposure that corresponds to 2.4 to $19.4 \mathrm{~d}$ of atmospheric equivalent photochemical age. Interestingly, unlike benzene oxidation, the concentrations of dimeric products decrease as the $\mathrm{OH}$ exposure increases, suggesting perhaps unfavorable dimer formation under conditions of high $\mathrm{OH}$ exposure for toluene oxidation. One potential contributor to the difference of the dependence of dimer formation on $\mathrm{OH}$ exposure is the more significant elevated $\mathrm{RO}_{2}$ concentrations ( 0.2 to $0.9 \mathrm{ppt}$ ) as the $\mathrm{OH}$ exposure increases more for benzene oxidation than that ( 0.3 to $0.5 \mathrm{ppt}$ ) for toluene oxidation, while the $\mathrm{HO}_{2}$ concentrations in the two sets of experiments are similar (1.5-2.4 ppb). The enhancement of $\mathrm{RO}_{2}$ concentrations may promote the dimer formation through the self- or crossreactions of $\mathrm{RO}_{2}$ (Mohr et al., 2017). On the other hand, a previous study indicates that the accretion of $\mathrm{RO}_{2}$ depends on the functional groups of the $\mathrm{RO}_{2}$ (Berndt et al., 2018). Whether the decreasing concentrations of dimeric products with $\mathrm{OH}$ exposure are related to the steric effects of the substituted methyl group of toluene requires further investigation. The overall atomic oxygen-to-carbon $(\mathrm{O}: \mathrm{C})$ ratios of HOM products increase from 1.18 to 1.26 for benzene oxidation and from 1.16 to 1.23 for toluene oxidation as the $\mathrm{OH}$ exposure increases, suggesting more oxygenated product distributions as detected. The overall atomic hydrogen-to-carbon $(\mathrm{H}: \mathrm{C})$ ratios of $\mathrm{HOMs}$ are $1.10-1.14$ for benzene oxidation and 1.14-1.18 for toluene oxidation, and the changes with $\mathrm{OH}$ exposure are negligible.

Figure $2 \mathrm{c}-\mathrm{d}$ show the concentrations of individual representative open-shell and closed-shell monomers for increasing $\mathrm{OH}$ exposures. The open-shell monomers are 
mainly $\mathrm{C}_{x} \mathrm{H}_{y+1} \mathrm{O}_{5}$ (BPRs) and $\mathrm{C}_{x} \mathrm{H}_{y+1} \mathrm{O}_{7}\left(\mathrm{RO}_{2}\right.$ formed from one more step of auto-oxidation). The concentrations of $\mathrm{C}_{x} \mathrm{H}_{y+1} \mathrm{O}_{7}$ are approximately 1 order of magnitude higher than the concentrations of $\mathrm{C}_{x} \mathrm{H}_{y+1} \mathrm{O}_{5}$. As described in Sect. 3.1, the further reactions of $\mathrm{C}_{x} \mathrm{H}_{y+1} \mathrm{O}_{5}$ and $\mathrm{C}_{x} \mathrm{H}_{y+1} \mathrm{O}_{7}$ may form closed-shell monomers, such as hydroperoxides $\left(\mathrm{C}_{x} \mathrm{H}_{y+2} \mathrm{O}_{5,7}\right)$, carbonyls $\left(\mathrm{C}_{x} \mathrm{H}_{y} \mathrm{O}_{4,6}\right)$, and alcohols $\left(\mathrm{C}_{x} \mathrm{H}_{y+2} \mathrm{O}_{4,6}\right.$; Mentel et al., 2015; Molteni et al., 2019), although these formulae may correspond to other functionalities, depending on the reaction rates and numbers of generation of autoxidation pathways. For multiple steps of auto-oxidation of BPRs or $\mathrm{RO}_{2}$ radicals $\left(\mathrm{C}_{x} \mathrm{H}_{y+1} \mathrm{O}_{5}\right.$ or $\left.\mathrm{C}_{x} \mathrm{H}_{y+1} \mathrm{O}_{7}\right)$, the products with two more hydrogen atoms than the precursor are plausibly hydroperoxides $\left(\mathrm{C}_{x} \mathrm{H}_{y+2} \mathrm{O}_{z}\right)$, if $z$ is an odd number, and alcohols, if it is an even number. On the other hand, products that have the same hydrogen atoms $\left(\mathrm{C}_{x} \mathrm{H}_{y} \mathrm{O}_{z}\right)$ are likely carbonyls with an even number of $z$. Instead, if the carbonyl formation involves the RO pathway, $\mathrm{C}_{x} \mathrm{H}_{y} \mathrm{O}_{z}$, with an odd number of $z$, may be formed. The concentrations of $\mathrm{C}_{x} \mathrm{H}_{y+2} \mathrm{O}_{7}$ and $\mathrm{C}_{x} \mathrm{H}_{y} \mathrm{O}_{6}$ originated from $\mathrm{C}_{x} \mathrm{H}_{y+1} \mathrm{O}_{7}$ are 1 to 2 orders of magnitudes greater than the concentrations of $\mathrm{C}_{x} \mathrm{H}_{y+2} \mathrm{O}_{5}$ and $\mathrm{C}_{x} \mathrm{H}_{y} \mathrm{O}_{4}$, which originated from $\mathrm{C}_{x} \mathrm{H}_{y+1} \mathrm{O}_{5}$. The greater signals of $\mathrm{O}_{7}$ products suggest our experimental conditions perhaps favor the formation of more oxygenated products.

Enhanced formation of more oxygenated products was observed for elevated $\mathrm{OH}$ exposures. For example, the concentrations of $\mathrm{C}_{6} \mathrm{H}_{7} \mathrm{O}_{7}$ increase first and stay relatively stable as the $\mathrm{OH}$ exposure increases, whereas the concentrations of $\mathrm{C}_{6} \mathrm{H}_{7} \mathrm{O}_{5}$ decrease at high $\mathrm{OH}$ exposures for benzene oxidation. The concentrations of the hydroperoxide products $\left(\mathrm{C}_{x} \mathrm{H}_{y+2} \mathrm{O}_{5,7}\right)$, such as $\mathrm{C}_{6} \mathrm{H}_{8} \mathrm{O}_{7}$, increase as $\mathrm{OH}$ exposure increases, whereas the concentrations of $\mathrm{C}_{6} \mathrm{H}_{8} \mathrm{O}_{5}$ decreases. For toluene oxidation, the concentrations of $\mathrm{C}_{x} \mathrm{H}_{y+2} \mathrm{O}_{5,7}$ $\left(\mathrm{C}_{7} \mathrm{H}_{10} \mathrm{O}_{5}\right.$ and $\left.\mathrm{C}_{7} \mathrm{H}_{10} \mathrm{O}_{7}\right)$ both decrease. The concentrations of carbonyl products $\left(\mathrm{C}_{x} \mathrm{H}_{y} \mathrm{O}_{4,6}\right)$ increase with $\mathrm{OH}$ exposure for benzene but not for toluene. We do not observe significant signals for $\mathrm{C}_{x} \mathrm{H}_{y+2} \mathrm{O}_{4}$ (alcohols) from BPR $\mathrm{C}_{x} \mathrm{H}_{y+1} \mathrm{O}_{5}$, but $\mathrm{C}_{x} \mathrm{H}_{y+2} \mathrm{O}_{6}$ from $\mathrm{RO}_{2} \mathrm{C}_{x} \mathrm{H}_{y+1} \mathrm{O}_{7}$ are of high concentrations. The concentrations of $\mathrm{C}_{6} \mathrm{H}_{8} \mathrm{O}_{6}$ (alcohol) from benzene also increase as the $\mathrm{OH}$ exposure increases, while the concentrations for $\mathrm{C}_{7} \mathrm{H}_{10} \mathrm{O}_{6}$ from toluene decrease. Overall, the enhanced formation of more oxygenated products at high $\mathrm{OH}$ exposure is more significant for benzene than for toluene. A possible explanation is that toluene oxidation may involve more multigeneration $\mathrm{OH}$ oxidation because of the substituted methyl group.

Increasing $\mathrm{OH}$ exposure also enhances the formation of more oxygenated fragmented products (Fig. S6 in the Supplement). $\mathrm{C}_{4} \mathrm{H}_{4} \mathrm{O}_{3}$ (perhaps epoxybutanedial) has been widely observed in aromatic oxidation (Wang et al., 2013; Wu et al., 2014; Zaytsev et al., 2019b). The concentrations of $\mathrm{C}_{4} \mathrm{H}_{4} \mathrm{O}_{3}$ decrease monotonically as the $\mathrm{OH}$ exposure increases for both benzene and toluene oxidation. For toluene oxidation, $\mathrm{C}_{3} \mathrm{H}_{4} \mathrm{O}_{2}$ (perhaps methylglyoxal), $\mathrm{C}_{4} \mathrm{H}_{4} \mathrm{O}_{2}$ (per- haps butenedial), and $\mathrm{C}_{5} \mathrm{H}_{6} \mathrm{O}_{2}$ (perhaps methylbutenedial) that were detected by the PTR-QiTOF also show similar monotonic decreases. By contrast, the concentrations of $\mathrm{C}_{3} \mathrm{H}_{4} \mathrm{O}_{5}, \mathrm{C}_{4} \mathrm{H}_{4} \mathrm{O}_{5}$, and $\mathrm{C}_{5} \mathrm{H}_{4} \mathrm{O}_{6}$ increase with increasing $\mathrm{OH}$ exposures for both benzene and toluene oxidation. The concentrations of other $\mathrm{O}_{5-7}$ products also increase as the $\mathrm{OH}$ exposure increases. Similar to the monomeric open-shell and closed-shell products, the increasing trends are more significant for benzene-derived products than those for toluenederived ones. This observation is in agreement with Garmash et al. (2020), who suggested that first-generation fragmented products were converted to more oxygenated ones through further oxidation as the $\mathrm{OH}$ exposure increases. Alternatively, these more oxygenated fragmented products might also be direct decomposition products of highly oxygenated RO radicals, which have been shown to play important roles in product formation (Noda et al., 2009; Birdsall and Elrod, 2011).

\section{Multigeneration $\mathrm{OH}$ oxidation}

In benzene and toluene $\left(\mathrm{C}_{x} \mathrm{H}_{y}\right)$ oxidation by $\mathrm{OH}$ radicals, we may expect that one $\mathrm{OH}$ addition could lead to termination products with hydrogen numbers of $y$ and $y+2$. When the second $\mathrm{OH}$ attack occurs, products with hydrogen numbers $<y$ and $>y+2$ may be produced by multigeneration $\mathrm{OH}$ reactions (Table S5 in the Supplement). For example, the closed-shell monomeric products from benzene oxidation should contain at least one double bond which can further react with $\mathrm{OH}$ radicals via $\mathrm{OH}$ addition to form products with two more hydrogen atoms (e.g., to form $\mathrm{C}_{6} \mathrm{H}_{10} \mathrm{O}_{z}$ ). The formation of $\mathrm{C}_{6} \mathrm{H}_{4} \mathrm{O}_{z}$ from the closed-shell monomeric products of benzene oxidation may involve multigeneration $\mathrm{OH}$ reactions via $\mathrm{H}$ abstraction and subsequent termination by a loss of $\mathrm{OH}$ or $\mathrm{HO}_{2}$ (Molteni et al., 2018; Garmash et al., 2020). There are significant contributions of products with hydrogen numbers $<y$ and $>y+2$ in our experiments (Tables S2 and S3), highlighting the importance of multigeneration $\mathrm{OH}$ reactions in production formation. On the other hand, the formation of $y$ and $y+2$ products may also involve multistep $\mathrm{OH}$ addition or $\mathrm{H}$ subtraction that make conversions between the two groups of products. For the phenolic pathway, the main products of $\mathrm{C}_{6} \mathrm{H}_{6} \mathrm{O}_{z}$ and $\mathrm{C}_{7} \mathrm{H}_{8} \mathrm{O}_{z}$ may be produced by dihydroxy- $\mathrm{OH}$, trihydroxy-OH, and even multiOH substituted benzene or toluene (Schwantes et al., 2017). The contributions of a third of the $\mathrm{OH}$ attack on the total of detected signals are often very low (Molteni et al., 2018).

Figure 3 shows the concentrations and the relative contributions of the closed-shell monomeric product groups, including $\mathrm{C}_{x} \mathrm{H}_{y-2} \mathrm{O}_{z}, \mathrm{C}_{x} \mathrm{H}_{y} \mathrm{O}_{z}, \mathrm{C}_{x} \mathrm{H}_{y+2} \mathrm{O}_{z}$, and $\mathrm{C}_{x} \mathrm{H}_{y+4} \mathrm{O}_{z}$. For both benzene and toluene oxidation, the concentrations of these monomers increase as the $\mathrm{OH}$ exposure increases for the atmospherically relevant equivalent photochemical age $(<10 \mathrm{~d})$. For greater $\mathrm{OH}$ exposures, the concentrations of $y-2$ products keep increasing, whereas the concentrations of 

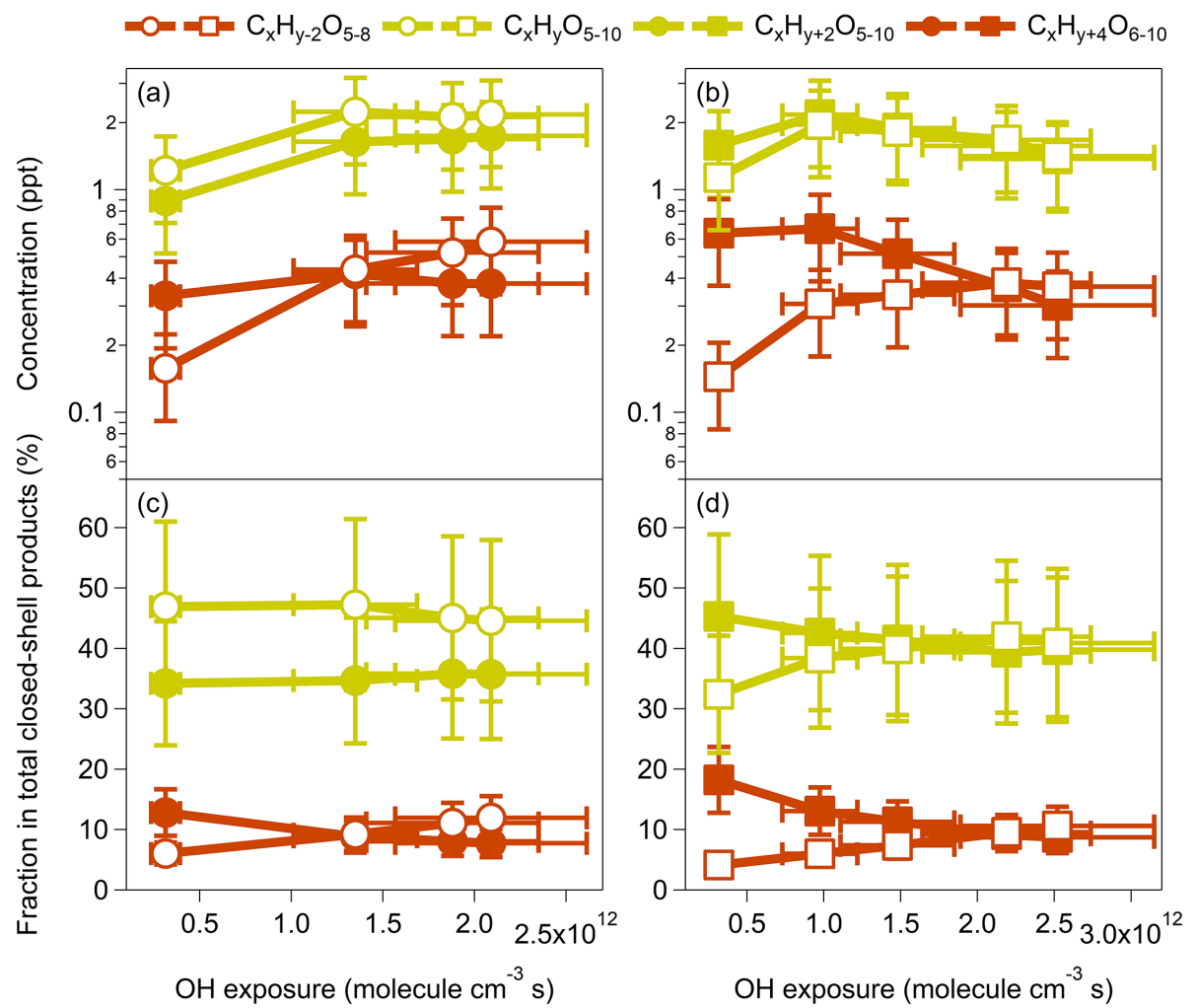

Figure 3. Concentrations and relative contributions of closed-shell monomeric products formed by benzene and toluene oxidation under low- $\mathrm{NO}_{x}$ conditions (OFR254-5) at various $\mathrm{OH}$ exposures. For the benzene oxidation, both $x$ and $y$ are 6 . For the toluene oxidation, $x$ is 7 , and $y$ is 8 .

other products start to decrease (Fig. 3a-b). The decreasing trends at high $\mathrm{OH}$ exposures are more significant for toluenederived products. Such differences might be explained by (1) the faster $\mathrm{OH}+\mathrm{VOC}$ rate for toluene than for benzene and (2) the methyl group in toluene and the added $-\mathrm{OH}$ groups during oxidation that may increase the electron density on the aromatic ring through a resonant electron-donating effect and, thereby, activate the aromatic ring and facilitate further addition reactions to form products with multiple $-\mathrm{OH}$ groups (M. Wang et al., 2020). Interestingly, the relative fractions of the $\mathrm{C}_{x} \mathrm{H}_{y-2} \mathrm{O}_{z}$ and $\mathrm{C}_{x} \mathrm{H}_{y+4} \mathrm{O}_{z}$ products for both benzene and toluene oxidation show opposite trends (Fig. 3c-d). The increasing fractions of $y$-2 products but decreasing fractions of $y+4$ products for increasing $\mathrm{OH}$ exposures, as well as the monotonically increasing concentration of $y$-2 products, suggest that the multigeneration $\mathrm{OH}$ oxidation may proceed preferably via $\mathrm{H}$ subtraction rather than $\mathrm{OH}$ addition, according to the current mechanistic understanding of aromatic oxidation. Garmash et al. (2020) also noted that higher $\mathrm{OH}$ concentrations caused a larger variety in HOM products, with $\mathrm{H}$ abstraction oxidation becoming possibly more significant. Compared with their precursors (benzene and toluene), the closed-shell monomeric products are less conjugated, and thus, $\mathrm{OH}$ addition is probably less favorable.

\section{Estimated molar yields}

Figure S7 in the Supplement shows the scatterplot of the concentrations of HOMs detected by $\mathrm{NO}_{3}^{-}$-TOF-CIMS and the VOC oxidation rate for benzene and toluene oxidation under low- $\mathrm{NO}_{x}$ conditions. As expected, the product concentrations increase with the VOC oxidation rates. To calculate the molar yields of HOM products, wall losses are corrected, including the loss in the sampling line, the loss to the OFR walls estimated by eddy diffusion, the loss to aerosol particles in the OFR (i.e., the condensation sink calculated on the basis of particle measurements), and the loss to non-condensable products due to continuous reaction with $\mathrm{OH}$ (Palm et al., 2016). Details are provided in Sect. S4 in the Supplement. Our estimated molar yields for the HOM products are $0.22 \pm 0.10 \%$ (mean \pm 1 standard deviation) for benzene oxidation and $0.46 \pm 0.20 \%$ for toluene oxidation. These yields are much lower than the smog chamber results of $4.1 \%$ to $14.0 \%$ for benzene oxidation reported by Garmash et al. (2020) but slightly greater than the flow tube yields of $0.1 \%$ to $0.2 \%$ reported by Molteni et al. (2018). A key difference in the experimental conditions is the much longer residence time in the chamber study (Table S4), suggesting, perhaps, a long characteristic time of HOM formation from aromatic oxidation. The study of 


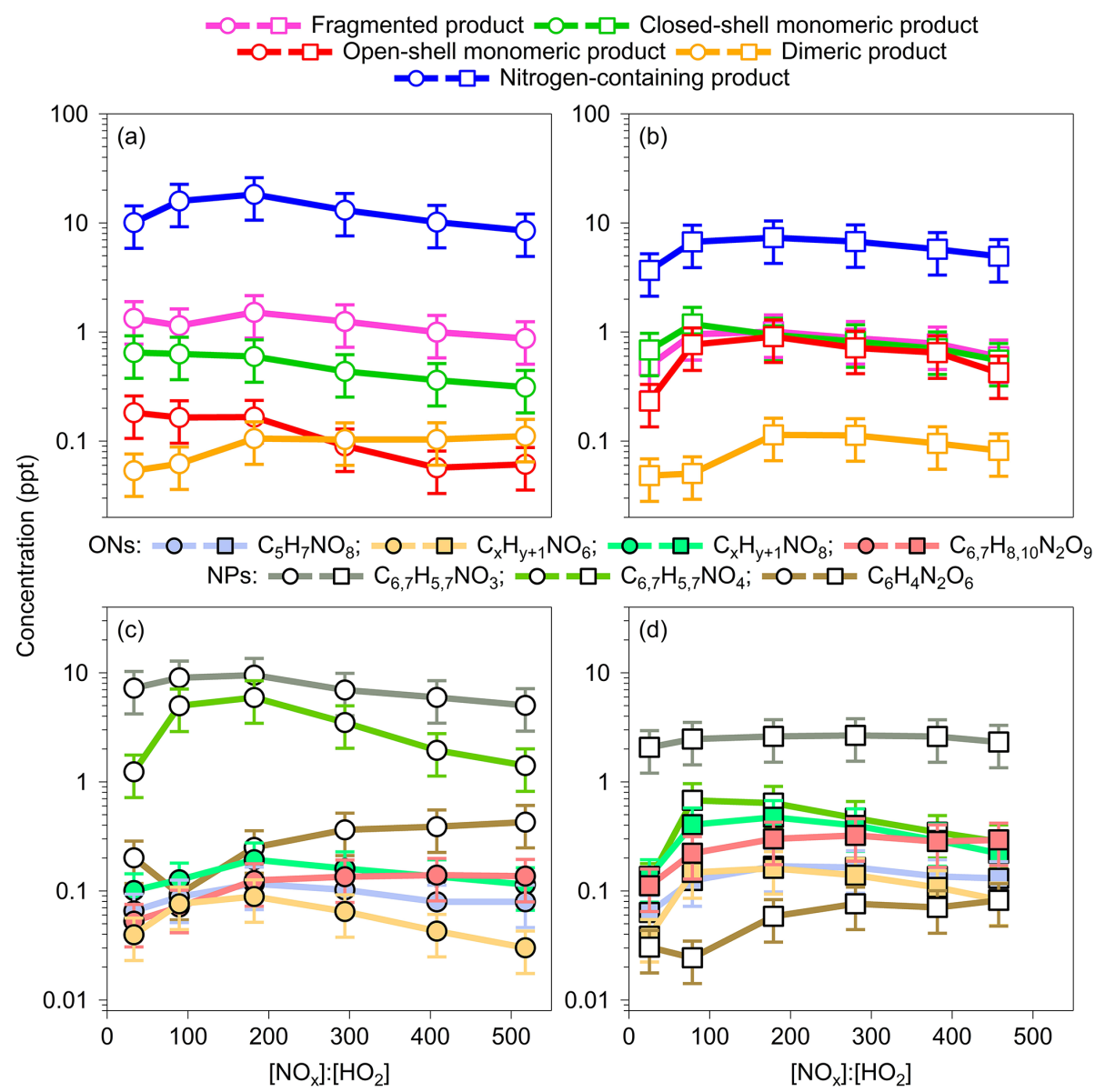

Figure 4. Concentrations of fragmented, monomeric closed-shell, open-shell, dimeric, and nitrogen-containing products formed by benzene and toluene oxidation under high- $\mathrm{NO}_{x}$ conditions (OFR254-5-iN $\left.2 \mathrm{O} 1.1 / 4.4\right)$ at various $\left[\mathrm{NO}_{x}\right]$ : $\left[\mathrm{HO}_{2}\right]$ levels. Data for OFR254-5-iN $2 \mathrm{O} 1.1$ experiments were averaged and are shown as the first data point in each panel. For the benzene oxidation, both $x$ and $y$ are 6 . For the toluene oxidation, $x$ is 7 , and $y$ is 8 .

Molteni et al. (2018) only provided the initial OH concentration (as listed in Table S4) that should decrease significantly as the reaction proceeded, for which we cannot rule out the possibility of low $\mathrm{OH}$ exposure that leads to fewer oxidation steps (i.e., lower yields of HOMs). Instrument sensitivity might also affect the detection of HOMs but is less likely to lead to orders of magnitude difference in the yields.

\subsection{High-NO ${ }_{x}$ conditions}

\section{Effects of $\mathrm{NO}_{x}$ level}

The $\mathrm{NO}$ or $\mathrm{NO}_{2}$ termination of $\mathrm{RO}_{2}$ radicals competes with the $\mathrm{HO}_{2}$ or $\mathrm{RO}_{2}$ termination and forms nitrogen-containing species at the expense of other highly oxygenated products (Tsiligiannis et al., 2019; Garmash et al., 2020; Y. Wang et al., 2020; Mehra et al., 2020). Yet, quantitative understanding in the effects of $\mathrm{NO}_{x}$ on the formation of oxygenated products is limited for aromatic precursors compared with those for biogenic VOCs (Nah et al., 2016; Lambe et al., 2017; Sarnela et al., 2018). The high- $\mathrm{NO}_{x}$ experiments herein were conducted with $\left[\mathrm{NO}_{2}\right]$ : [NO] ratios of 20 to 120 (Table S1), which may represent urban afternoon conditions when fresh $\mathrm{NO}_{x}$ emission is mostly converted to $\mathrm{NO}_{2}$, and intense photochemistry fuels the oxidation of aromatics accompanying the $\mathrm{NO}_{x}$ emission (Newland et al., 2021). Figure 4 shows the concentrations of observed HOMs for various $\left[\mathrm{NO}_{x}\right]:\left[\mathrm{HO}_{2}\right]$ conditions. We use $\left[\mathrm{NO}_{x}\right]:\left[\mathrm{HO}_{2}\right]$ instead of $[\mathrm{NO}]:\left[\mathrm{HO}_{2}\right]$ to evaluate termination pathways to form various nitrogen-containing products such as nitrated phenols, organic nitrate, and peroxynitrate. The contributions from $\mathrm{RO}_{2}+\mathrm{RO}_{2}$ termination are probably minor because of the low concentrations of $\mathrm{RO}_{2}(<0.9 \mathrm{ppt})$. Given the low and narrow range of $\mathrm{NO}_{x}$ levels in the OFR254-i $\mathrm{N}_{2} \mathrm{O} 1.1$ experiments, the product concentrations for all lamp voltages (i.e., a range of $\mathrm{OH}$ exposure) are averaged and shown as the first data point in each panel of Fig. 4.

Similar to previous findings, nitrogen-containing products are the dominant species in the spectra, with concentrations up to 18.3 and $7.3 \mathrm{ppt}$ for benzene and toluene oxidation, re- 

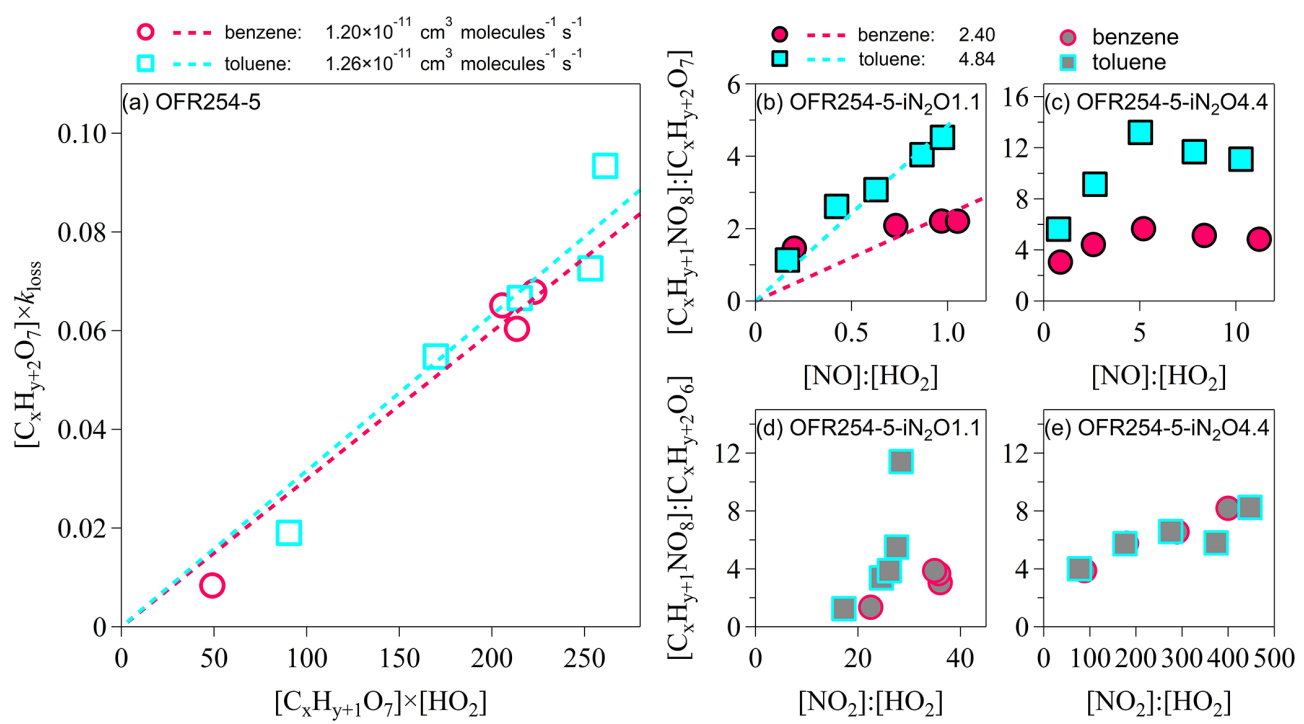

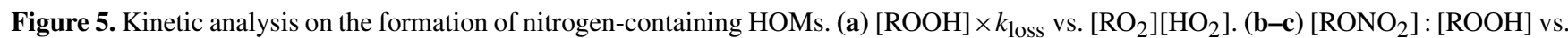
$[\mathrm{NO}]:\left[\mathrm{HO}_{2}\right]$. (d-e) $\left[\mathrm{RC}(\mathrm{O}) \mathrm{OONO}_{2}\right]:[\mathrm{ROOH}]$ vs. $\left[\mathrm{NO}_{2}\right]:\left[\mathrm{HO}_{2}\right]$. For the benzene oxidation, both $x$ and $y$ are 6 . For the toluene oxidation, $x$ is 7 , and $y$ is $8 . k_{\text {loss }}$ represents the loss rate of the corresponding HOM products in units per second (hereafter $\mathrm{s}^{-1}$ ).

spectively. The concentrations of all HOMs start to decrease at high $\left[\mathrm{NO}_{x}\right]:\left[\mathrm{HO}_{2}\right]$ ratios, except that the concentrations of dimeric products from benzene oxidation remain steady (Fig. 4a-b). The decreasing trends for monomeric closedshell, open-shell, and fragmented products are expected, indicating significant competition of radical terminations by $\mathrm{NO}$ or $\mathrm{NO}_{2}$. The decreasing concentrations of nitrogencontaining products for increasing $\left[\mathrm{NO}_{x}\right]:\left[\mathrm{HO}_{2}\right]$ are, however, counterintuitive. Figure $4 \mathrm{c}-\mathrm{d}$ show the concentrations of main individual nitrogen-containing products. The initial increase in the concentrations of nitrogen-containing species might be explained by a decrease in $\mathrm{HO}_{2}$ concentrations from $0.8-1.5$ to $0.5-0.7 \mathrm{ppb}$ as a result of the switch of $1.1 \%$ of $\mathrm{N}_{2} \mathrm{O}$ injection to $4.4 \%$ (Table $\mathrm{S} 1$ ). The further reduction in these compounds as $\left[\mathrm{NO}_{x}\right]:\left[\mathrm{HO}_{2}\right]$ increases is probably related to the simultaneous decrease in $\mathrm{RO}_{2}$ or, alternatively, further reactions to products that have two nitrogen atoms. Figure S8 in the Supplement shows similar concentration trends for individual ring scission and ring-retaining products with or without nitrogen in their formulas. There seem to be optimal $\left[\mathrm{NO}_{x}\right]:\left[\mathrm{HO}_{2}\right]$ ratios of 130 to 240 for the formation of nitrogen-containing products. The dependence of those products with only one nitrogen atom on $\mathrm{NO}_{x}$ is, however, not strong. The availability of $\mathrm{RO}_{2}$ is perhaps the key factor that limits their formation at low $\mathrm{NO}_{x}$ levels and affects further reactions to form products with two nitrogen atoms at high $\mathrm{NO}_{x}$ levels.

Nitrated phenols are the most abundant nitrogencontaining products under high- $\mathrm{NO}_{x}$ conditions. In aromatic oxidation, these compounds are formed by the reaction of phenoxy $\mathrm{RO}$ radicals with $\mathrm{NO}_{2}$ (Jenkin et al., 2003). In the Master Chemical Mechanism (MCMv3.3.1), the phe- noxy $\mathrm{RO}$ radicals can be formed via $\mathrm{OH}$ oxidation of phenols $\left(k_{\mathrm{OH}}=2.8 \times 10^{-11} \mathrm{~cm}^{3} \mathrm{~mol}^{-1} \mathrm{~s}^{-1}\right)$, with a low branching ratio of 0.06 . They can also be formed by the $\mathrm{NO}_{3}$ oxidation of phenols $\left(k_{\mathrm{NO}_{3}}=3.8 \times 10^{-12} \mathrm{~cm}^{3} \mathrm{~mol}^{-1} \mathrm{~s}^{-1}\right)$, with a high branching ratio of 0.74 (IUPAC, 2008). Under high$\mathrm{NO}_{x}$ conditions, the estimated concentrations of $\mathrm{OH}$ and $\mathrm{NO}_{3}$ radicals are 0.05 to $0.3 \mathrm{ppb}$ and 0.01 to $0.09 \mathrm{ppb}$, respectively, suggesting that the $\mathrm{NO}_{3}$ oxidation of phenols contributed efficiently to the formation of nitrated phenols in the OFR experiments herein. When $\left[\mathrm{NO}_{x}\right]:\left[\mathrm{HO}_{2}\right]$ increases, the concentrations of $\mathrm{C}_{6,7} \mathrm{H}_{5,7} \mathrm{NO}_{4}$ (perhaps nitrocatechol or methylnitrocatechol) increase first and then decrease. The concentrations of $\mathrm{C}_{6,7} \mathrm{H}_{5,7} \mathrm{NO}_{3}$ (perhaps nitrophenol or methylnitrophenol), however, show a weak dependence on the $\mathrm{NO}_{x}$ level, suggesting the availability of RO radical might be the limiting factor in controlling the formation of nitrated phenols herein. Interestingly, the concentrations of products with two nitrogen atoms such as $\mathrm{C}_{6} \mathrm{H}_{4} \mathrm{~N}_{2} \mathrm{O}_{6}, \mathrm{C}_{6} \mathrm{H}_{8} \mathrm{~N}_{2} \mathrm{O}_{9}$, and $\mathrm{C}_{7} \mathrm{H}_{10} \mathrm{~N}_{2} \mathrm{O}_{9}$ (only for toluene) steadily increase as $\left[\mathrm{NO}_{x}\right]:\left[\mathrm{HO}_{2}\right]$ rises, suggesting a strong dependence of the formation of these species on $\mathrm{NO}_{2}$.

\section{Formation of $\mathrm{ROOH}, \mathrm{RONO}_{2}$, and $\mathrm{ROONO}_{2}$}

Jenkin et al. (2019) suggested that the overall rate coefficients for $\mathrm{RO}_{2}+\mathrm{HO}_{2}$ reactions are $1.92 \times 10^{-11}$ and $1.98 \times$ $10^{-11} \mathrm{~cm}^{3} \mathrm{~mol}^{-1} \mathrm{~s}^{-1}$ at $298 \mathrm{~K}$ for benzene and toluene oxidation, respectively. For the OFR conditions (Table S1), the characteristic time for the $\mathrm{RO}_{2}$ termination by $\mathrm{HO}_{2}$ was perhaps $<10 \mathrm{~s}$, which is much shorter than the OFR residence time of $95 \mathrm{~s}$. The rate coefficients of the hydroperoxide pathway $\left(\mathrm{RO}_{2}+\mathrm{HO}_{2} \rightarrow \mathrm{ROOH}+\mathrm{O}_{2}\right)$ may be con- 
strained by the concentration ratios of $[\mathrm{ROOH}]$ multiplied by the loss rate of $\mathrm{ROOH}$ to $\left[\mathrm{RO}_{2}\right]\left[\mathrm{HO}_{2}\right]$ (Sect. S5 in the Supplement). For example, assuming that the $\mathrm{C}_{6} \mathrm{H}_{7} \mathrm{O}_{7}$ and $\mathrm{C}_{7} \mathrm{H}_{9} \mathrm{O}_{7}$ are the $\mathrm{RO}_{2}$ radicals, and $\mathrm{C}_{6} \mathrm{H}_{8} \mathrm{O}_{7}$ and $\mathrm{C}_{7} \mathrm{H}_{10} \mathrm{O}_{7}$ are the corresponding $\mathrm{ROOH}$ for benzene and toluene oxidation, respectively, the slopes in Fig. 5a indicate that the rate coefficients of hydroperoxides are $1.20 \times 10^{-11}$ and $1.26 \times 10^{-11} \mathrm{~cm}^{3} \mathrm{~mol}^{-1} \mathrm{~s}^{-1}$. These rate coefficients suggest that the branching ratios of the hydroperoxide formation under low- $\mathrm{NO}_{x}$ conditions are 0.62 and 0.64 for benzene- and toluene-derived $\mathrm{RO}_{2}$, respectively, which are consistent with the estimated branching ratios of $0.52-1.00$ in the literature (Jenkin et al., 2019).

In the presence of $\mathrm{NO}_{x}$, the reactions between $\mathrm{C}_{x} \mathrm{H}_{y+1} \mathrm{O}_{7}$ and nitrogen oxides lead to both chain propagation and chain termination to form RO radicals and nitrogen-containing products. Similar to the analysis of the hydroperoxide formation, the slopes in Fig. 5b suggest that the rate coefficients of $\mathrm{RO}_{2}+\mathrm{NO}(+\mathrm{M}) \rightarrow \mathrm{RONO}_{2}(+\mathrm{M})$ are $2.87 \times 10^{-11}$ and $6.12 \times 10^{-11} \mathrm{~cm}^{3} \mathrm{~mol}^{-1} \mathrm{~s}^{-1}$ for benzene and toluene oxidation under OFR254-5-i $\mathrm{N}_{2} \mathrm{O} 1.1$ conditions, respectively (Sect. S5). These coefficients are more than 1 order of magnitude greater than the values reported by Jenkin et al. (2019; i.e., $8.09 \times 10^{-13}$ and $1.10-8.45 \times 10^{-13} \mathrm{~cm}^{3} \mathrm{~mol}^{-1} \mathrm{~s}^{-1}$ for benzene and toluene oxidation, respectively). One explanation is that the detected $\mathrm{C}_{x} \mathrm{H}_{y+1} \mathrm{NO}_{8}$ contains multifunctional groups and represents not only non-peroxy organic nitrates $\left(\mathrm{RONO}_{2}\right)$ but also peroxy organic nitrates $\left(\mathrm{ROONO}_{2}\right)$. As shown in Fig. $5 c$, the $\left[\mathrm{C}_{x} \mathrm{H}_{y+1} \mathrm{NO}_{8}\right]:\left[\mathrm{C}_{x} \mathrm{H}_{y+2} \mathrm{O}_{7}\right]$ ratios start to decrease at higher [NO]: $\left[\mathrm{HO}_{2}\right]$ in our OFR254$5-\mathrm{iN}_{2} \mathrm{O} 4.4$ experiments. The competition between $\mathrm{NO}$ and $\mathrm{HO}_{2}$ for terminating $\mathrm{RO}_{2}$ should not alter the rate coefficients and the branching ratios (Atkinson and Arey, 2003). The lack of a linear relationship of $\left[\mathrm{C}_{x} \mathrm{H}_{y+1} \mathrm{NO}_{8}\right]:\left[\mathrm{C}_{x} \mathrm{H}_{y+2} \mathrm{O}_{7}\right]$ (i.e., assumed as $\left[\mathrm{RONO}_{2}\right]$ : $[\mathrm{ROOH}]$ ) on $[\mathrm{NO}]:\left[\mathrm{HO}_{2}\right]$ ratio is consistent, with the possibility of $\mathrm{C}_{x} \mathrm{H}_{y+1} \mathrm{O}_{8}$ partially being $\mathrm{ROONO}_{2}$, especially for toluene oxidation.

$\mathrm{Xu}$ et al. (2020) indicate that the formation of nonperoxy organic nitrates $\left(\mathrm{RONO}_{2}\right)$ is minor in aromatic oxidation. The detected $\mathrm{ROONO}_{2}$ are likely $\mathrm{RC}(\mathrm{O}) \mathrm{OONO}_{2}$ because $\mathrm{ROONO}_{2}$ are usually thermally unstable intermediates (Kirchner et al., 1999), and $\mathrm{RC}(\mathrm{O}) \mathrm{OONO}_{2}$ can be detected by the $\mathrm{NO}_{3}^{-}$-TOF-CIMS (Rissanen, 2018). Acyl peroxy radicals $\mathrm{RC}(\mathrm{O}) \mathrm{OO}$ (i.e., a type of peroxy radical) may react with $\mathrm{NO}_{2}$ to produce peroxyacyl nitrate $\left(\mathrm{RC}(\mathrm{O}) \mathrm{OONO}_{2}\right.$; Jenkin et al., 2019). The formation of the $\mathrm{RC}(\mathrm{O}) \mathrm{OONO}_{2}$ requires (1) the original $\mathrm{RO}_{2}$ radicals to be $\mathrm{C}_{x} \mathrm{H}_{y+1} \mathrm{O}_{6}$ instead of $\mathrm{C}_{x} \mathrm{H}_{y+1} \mathrm{O}_{7}$, and (2) an acyl $(-\mathrm{C}=\mathrm{O})$ group that is connected to the $\mathrm{O}-\mathrm{O}$ bond. The formation of $\mathrm{C}_{x} \mathrm{H}_{y+1} \mathrm{O}_{6}$ is feasible through the RO pathway (Sect. S3). The hydroperoxides corresponding to $\mathrm{C}_{x} \mathrm{H}_{y+1} \mathrm{O}_{6}$ are $\mathrm{C}_{x} \mathrm{H}_{y+2} \mathrm{O}_{6}$ (i.e., $\mathrm{C}_{6} \mathrm{H}_{8} \mathrm{O}_{6}$ and $\mathrm{C}_{7} \mathrm{H}_{10} \mathrm{O}_{6}$ for benzene and toluene, respectively). Figure 5d-e show the increase in $\left[\mathrm{C}_{x} \mathrm{H}_{y+1} \mathrm{NO}_{8}\right]:\left[\mathrm{C}_{x} \mathrm{H}_{y+2} \mathrm{O}_{6}\right]$ (i.e., perhaps $\left[\mathrm{RC}(\mathrm{O}) \mathrm{OONO}_{2}\right]:[\mathrm{ROOH}]$ ) for increasing $\left[\mathrm{NO}_{2}\right]:\left[\mathrm{HO}_{2}\right]$ ratios. In particular, the relationship be- tween $\left[\mathrm{C}_{x} \mathrm{H}_{y+1} \mathrm{NO}_{8}\right]:\left[\mathrm{C}_{x} \mathrm{H}_{y+2} \mathrm{O}_{6}\right]$ and $\left[\mathrm{NO}_{2}\right]:\left[\mathrm{HO}_{2}\right]$ is nearly linear at high $\left[\mathrm{NO}_{2}\right]$ : $\left[\mathrm{HO}_{2}\right]$ ratios in the OFR2545-iN $\mathrm{N}_{2} \mathrm{O} 4.4$ experiments. There is a lack of kinetic data for the reactions of $\mathrm{RC}(\mathrm{O}) \mathrm{OO}+\mathrm{NO}_{2}$ (Rissanen, 2018), which prevents us from further investigation.

\section{Atmospheric implications}

In this study, we investigated the formation of HOMs in the OFR by the oxidation of benzene and toluene in a wide range of $\mathrm{OH}$ exposure and $\mathrm{NO}_{x}$ conditions. Recent findings emphasize the significance of the bicyclic channel in the oxidation of light aromatics (Wang et al., 2017; Molteni et al., 2018; Tsiligiannis et al., 2019; Zaytsev et al., 2019b; Garmash et al., 2020; Y. Wang et al., 2020). The presence of $\mathrm{NO}_{x}$ enhances the formation of organonitrates and even dinitrate organic compounds. Extensive autoxidation and accretion reaction has been reported for substituted aromatics (Y. Wang et al., 2020). Our results show enhanced formation of more oxygenated products for elevated $\mathrm{OH}$ exposures. The formation of dimeric products, however, seems unfavorable under conditions of high $\mathrm{OH}$ exposure and low $\mathrm{NO}_{x}$ for substituted aromatics. The suppression of dimeric products may affect the contribution of aromatic HOMs to new particle formation in the downwind of urban atmosphere. The changes in product distribution and concentration highlight the possibility that multigeneration $\mathrm{OH}$ oxidation proceed preferably via $\mathrm{H}$ subtraction rather than $\mathrm{OH}$ addition, although one HOM formula may correspond to various functionalities. For aged air masses, this may reduce the $\mathrm{H}: \mathrm{C}$ ratios of $\mathrm{HOM}$ products from aromatic oxidation. Under high- $\mathrm{NO}_{x}$ conditions, we show that the formation of products containing one nitrogen atom perhaps depends more significantly on the organic radicals $\left(\mathrm{RO}\right.$ or $\left.\mathrm{RO}_{2}\right)$ but less so on $\mathrm{NO}_{2}$, while the formation of products containing two nitrogen atoms depends significantly on $\mathrm{NO}_{2}$. Further investigation on the roles of high- $\mathrm{NO}_{2}$ conditions that represent a wide range of anthropogenically influenced environments in the oxidation of aromatic VOCs are needed. Moreover, we found that non-peroxy organic nitrates might form via $\mathrm{RO}_{2}+\mathrm{NO}$ under low- $\mathrm{NO}_{2}$ conditions, and $\mathrm{RO}_{2}+\mathrm{NO}_{2}$ may dominate to produce $\mathrm{ROONO}_{2}$ or $\mathrm{RC}(\mathrm{O}) \mathrm{OONO}_{2}$ under high- $\mathrm{NO}_{2}$ conditions. The reaction of $\mathrm{RC}(\mathrm{O}) \mathrm{OO}$ with $\mathrm{NO}_{2}$ to produce peroxyacyl nitrates should be of particular importance with high $\left[\mathrm{NO}_{2}\right]$ : [NO] ratios of tens to hundreds. Both of $\mathrm{ROONO}_{2}$ and $\mathrm{RC}(\mathrm{O}) \mathrm{OONO}_{2}$ are reservoirs of $\mathrm{RO}_{2}$ radicals. Under conditions of high $\left[\mathrm{NO}_{2}\right]$ : [NO] ratios (e.g., late afternoon in urban or suburban environments), the effective lifetimes of $\mathrm{RO}_{2}$ radicals might become longer because of the formation of $\mathrm{RC}(\mathrm{O}) \mathrm{OONO}_{2}$. Subsequent slow release of $\mathrm{RO}_{2}$ radicals with the help of $\mathrm{NO}_{2}$ may extend the formation of HOMs from VOC oxidation in urban environments to early evening, when $\mathrm{OH}$ starts to decline and $\mathrm{NO}_{3}$ has not yet built up, facilitating the development of regional SOA pollution. 
Data availability. Data presented in this paper are available upon request to the corresponding author.

Supplement. The supplement related to this article is available online at: https://doi.org/10.5194/acp-21-12005-2021-supplement.

Author contributions. QC and YJL designed the study. XC conducted the experiments and data analysis, with the help of $\mathrm{YZ}, \mathrm{KL}$, and GH. QC, YJL, and XC wrote the paper.

Competing interests. The authors declare that there is no conflict of interest.

Disclaimer. Publisher's note: Copernicus Publications remains neutral with regard to jurisdictional claims in published maps and institutional affiliations.

Acknowledgements. This work has been supported by the MOST National Key R\&D Program of China (grant no. 2017YFC0213000; Task 3), the National Natural Science Foundation of China (grant nos. 41875165, 41961134034, and51861135102), the 111 Project of Urban Air Pollution and Health Effects (grant no. B20009), the Science and Technology Development Fund, Macau SAR (grant no. 0019/2020/A1), and the University of Macau (grant no. MYRG2018-00006-FST). The authors thank Tong Zhu, Ying Liu, Manjula R. Canagaratna, Andrew Lambe, and Peng Zhe for the instrument support and helpful discussion.

Financial support. This research has been supported by the Ministry of Science and Technology of the People's Republic of China (grant no. 2017YFC0213000; Task 3), the National Natural Science Foundation of China (grant nos. 41875165, 41961134034, and 51861135102), the Higher Education Discipline Innovation Project (grant no. B20009), the Fundo para o Desenvolvimento das Ciências e da Tecnologia (grant no. 0019/2020/A1), and the Universidade de Macau (grant no. MYRG2018-00006-FST).

Review statement. This paper was edited by Arthur Chan and reviewed by two anonymous referees.

\section{References}

Arey, J., Obermeyer, G., Aschmann, S. M., Chattopadhyay, S., Cusick, R. D., and Atkinson, R.: Dicarbonyl products of the $\mathrm{OH}$ radical-initiated reaction of a series of aromatic hydrocarbons, Environ. Sci. Technol., 43, 683-689, https://doi.org/10.1021/es8019098, 2009.

Atkinson, R.: Atmospheric chemistry of VOCs and $\mathrm{NO}_{x}$, Atmos. Environ., 34, 2063-2101, https://doi.org/10.1016/S13522310(99)00460-4, 2000.
Atkinson, R. and Arey, J.: Atmospheric degradation of volatile organic compounds, Chem. Rev., 103, 4605-4638, https://doi.org/10.1021/cr0206420, 2003.

Berndt, T., Richters, S., Jokinen, T., Hyttinen, N., Kurten, T., Otkjaer, R. V., Kjaergaard, H. G., Stratmann, F., Herrmann, H., Sipila, M., Kulmala, M., and Ehn, M.: Hydroxyl radical-induced formation of highly oxidized organic compounds, Nat. Commun., 7, 13677, https://doi.org/10.1038/ncomms13677, 2016.

Berndt, T., Scholz, W., Mentler, B., Fischer, L., Herrmann, H., Kulmala, M., and Hansel, A.: Accretion product formation from self- and cross-reactions of $\mathrm{RO} 2$ radicals in the atmosphere, Angew. Chem.-Ger. Edit., 57, 3820-3824, https://doi.org/10.1002/anie.201710989, 2018.

Bianchi, F., Kurten, T., Riva, M., Mohr, C., Rissanen, M. P., Roldin, P., Berndt, T., Crounse, J. D., Wennberg, P. O., Mentel, T. F., Wildt, J., Junninen, H., Jokinen, T., Kulmala, M., Worsnop, D. R., Thornton, J. A., Donahue, N., Kjaergaard, H. G., and Ehn, M.: Highly oxygenated organic molecules (HOM) from gas-phase autoxidation involving peroxy radicals: a key contributor to atmospheric aerosol, Chem. Rev., 119, 3472-3509, https://doi.org/10.1021/acs.chemrev.8b00395, 2019.

Birdsall, A. W. and Elrod, M. J.: Comprehensive NO-dependent study of the products of the oxidation of atmospherically relevant aromatic compounds, J. Phys. Chem. A, 115, 5397-5407, https://doi.org/10.1021/jp2010327, 2011.

Birdsall, A. W., Andreoni, J. F., and Elrod, M. J.: Investigation of the role of bicyclic peroxy radicals in the oxidation mechanism of toluene, J. Phys. Chem. A, 114, 10655-10663, https://doi.org/10.1021/jp105467e, 2010.

Brophy, P. and Farmer, D. K.: A switchable reagent ion high resolution time-of-flight chemical ionization mass spectrometer for real-time measurement of gas phase oxidized species: characterization from the 2013 southern oxidant and aerosol study, Atmos. Meas. Tech., 8, 2945-2959, https://doi.org/10.5194/amt-8-29452015, 2015.

Calvert, J. G., Atkinson, R., Becker, K. H., Kamens, R. M., Seinfeld, J. H., Wallington, T. J., and Yarwood, G. Y.: The mechanisms of atmospheric oxidation of aromatic hydrocarbons, Oxford University Press, New York, 2002.

Calvert, J. G., Orlando, J. J., Stockwell, W. R., and Wallington, T. J.: The mechanisms of reactions influencing atmospheric ozone, Oxford University Press, New York, 2015.

Cheng, X., Chen, Q., Li, Y., Huang, G., Liu, Y., Lu, S., Zheng, Y., Qiu, W., Lu, K., Qiu, X., Bianchi, F., Yan, C., Yuan, B., Shao, M., Wang, Z., Canagaratna, M. R., Zhu, T., Wu, Y., and Zeng, L.: Secondary Production of Gaseous Nitrated Phenols in Polluted Urban Environments, Environ. Sci. Technol., 55, 4410-4419, https://doi.org/10.1021/acs.est.0c07988, 2021.

Crounse, J. D., Nielsen, L. B., Jørgensen, S., Kjaergaard, H. G., and Wennberg, P. O.: Autoxidation of organic compounds in the atmosphere, J. Phys. Chem. Lett., 4, 3513-3520, https://doi.org/10.1021/jz4019207, 2013.

Ehn, M., Thornton, J. A., Kleist, E., Sipila, M., Junninen, H., Pullinen, I., Springer, M., Rubach, F., Tillmann, R., Lee, B., Lopez-Hilfiker, F., Andres, S., Acir, I. H., Rissanen, M., Jokinen, T., Schobesberger, S., Kangasluoma, J., Kontkanen, J., Nieminen, T., Kurten, T., Nielsen, L. B., Jorgensen, S., Kjaergaard, H. G., Canagaratna, M., Dal Maso, M., Berndt, T., Petaja, T., Wahner, A., Kerminen, V. M., Kulmala, M., 
Worsnop, D. R., Wildt, J., and Mentel, T. F.: A large source of low-volatility secondary organic aerosol, Nature, 506, 476-479, https://doi.org/10.1038/nature13032, 2014.

Gallimore, P. J., Achakulwisut, P., Pope, F. D., Davies, J. F., Spring, D. R., and Kalberer, M.: Importance of relative humidity in the oxidative ageing of organic aerosols: case study of the ozonolysis of maleic acid aerosol, Atmos. Chem. Phys., 11, 12181-12195, https://doi.org/10.5194/acp-11-12181-2011, 2011.

Garmash, O., Rissanen, M. P., Pullinen, I., Schmitt, S., Kausiala, O., Tillmann, R., Zhao, D., Percival, C., Bannan, T. J., Priestley, M., Hallquist, A. M., Kleist, E., Kiendler-Scharr, A., Hallquist, M., Berndt, T., McFiggans, G., Wildt, J., Mentel, T. F., and Ehn, M.: Multi-generation $\mathrm{OH}$ oxidation as a source for highly oxygenated organic molecules from aromatics, Atmos. Chem. Phys., 20, 515-537, https://doi.org/10.5194/acp-20-515-2020, 2020.

Gowda, D. and Kawamura, K.: Seasonal variations of low molecular weight hydroxy-dicarboxylic acids and oxaloacetic acid in remote marine aerosols from Chichijima Island in the western North Pacific (December 2010-November 2011), Atmos. Res., 204, 128-135, https://doi.org/10.1016/j.atmosres.2018.01.007, 2018.

Heinritzi, M., Simon, M., Steiner, G., Wagner, A. C., Kürten, A., Hansel, A., and Curtius, J.: Characterization of the massdependent transmission efficiency of a CIMS, Atmos. Meas. Tech., 9, 1449-1460, https://doi.org/10.5194/amt-9-1449-2016, 2016.

Huang, G., Liu, Y., Shao, M., Li, Y., Chen, Q., Zheng, Y., Wu, Z., Liu, Y., Wu, Y., Hu, M., Li, X., Lu, S., Wang, C., Liu, J., Zheng, M., and Zhu, T.: Potentially important contribution of gas-phase oxidation of naphthalene and methylnaphthalene to secondary organic aerosol during haze events in Beijing, Environ. Sci. Technol., 53, 1235-1244, https://doi.org/10.1021/acs.est.8b04523, 2019.

Hyttinen, N., Kupiainen-Määttä, O., Rissanen, M. P., Muuronen, M., Ehn, M., and Kurtén, T.: Modeling the charging of highly oxidized cyclohexene ozonolysis products using nitratebased chemical ionization, J. Phys. Chem. A, 119, 6339-6345, https://doi.org/10.1021/acs.jpca.5b01818, 2015.

IUPAC: available at: http://iupac.pole-ether.fr (last access: 24 July 2021), 2008.

Jenkin, M. E., Saunders, S. M., Wagner, V., and Pilling, M. J.: Protocol for the development of the Master Chemical Mechanism, MCM v3 (Part B): tropospheric degradation of aromatic volatile organic compounds, Atmos. Chem. Phys., 3, 181-193, https://doi.org/10.5194/acp-3-181-2003, 2003.

Jenkin, M. E., Valorso, R., Aumont, B., and Rickard, A. R.: Estimation of rate coefficients and branching ratios for reactions of organic peroxy radicals for use in automated mechanism construction, Atmos. Chem. Phys., 19, 7691-7717, https://doi.org/10.5194/acp-19-7691-2019, 2019.

Jokinen, T., Sipilä, M., Junninen, H., Ehn, M., Lönn, G., Hakala, J., Petäjä, T., Mauldin III, R. L., Kulmala, M., and Worsnop, D. R.: Atmospheric sulphuric acid and neutral cluster measurements using CI-APi-TOF, Atmos. Chem. Phys., 12, 4117-4125, https://doi.org/10.5194/acp-12-4117-2012, 2012.

Kirchner, F., Mayer-Figge, A., Zabel, F., and Becker, K. H.: Thermal stability of peroxynitrates, Int. J. Chem. Kinet., 31, 127-144, https://doi.org/10.1002/(sici)1097-4601(1999)31:2<127::aidkin6>3.0.co;2-1, 1999.
Lambe, A., Massoli, P., Zhang, X., Canagaratna, M., Nowak, J., Daube, C., Yan, C., Nie, W., Onasch, T., Jayne, J., Kolb, C., Davidovits, P., Worsnop, D., and Brune, W.: Controlled nitric oxide production via $\mathrm{O}\left({ }^{1} \mathrm{D}\right)+\mathrm{N}_{2} \mathrm{O}$ reactions for use in oxidation flow reactor studies, Atmos. Meas. Tech., 10, 2283-2298, https://doi.org/10.5194/amt-10-2283-2017, 2017.

Lambe, A. T., Ahern, A. T., Williams, L. R., Slowik, J. G., Wong, J. P. S., Abbatt, J. P. D., Brune, W. H., Ng, N. L., Wright, J. P., Croasdale, D. R., Worsnop, D. R., Davidovits, P., and Onasch, T. B.: Characterization of aerosol photooxidation flow reactors: heterogeneous oxidation, secondary organic aerosol formation and cloud condensation nuclei activity measurements, Atmos. Meas. Tech., 4, 445-461, https://doi.org/10.5194/amt-4445-2011, 2011.

Li, L., Tang, P., Nakao, S., and Cocker III, D. R.: Impact of molecular structure on secondary organic aerosol formation from aromatic hydrocarbon photooxidation under low$\mathrm{NO}_{x}$ conditions, Atmos. Chem. Phys., 16, 10793-10808, https://doi.org/10.5194/acp-16-10793-2016, 2016.

Mehra, A., Wang, Y., Krechmer, J. E., Lambe, A., Majluf, F., Morris, M. A., Priestley, M., Bannan, T. J., Bryant, D. J., Pereira, K. L., Hamilton, J. F., Rickard, A. R., Newland, M. J., Stark, H., Croteau, P., Jayne, J. T., Worsnop, D. R., Canagaratna, M. R., Wang, L., and Coe, H.: Evaluation of the chemical composition of gas- and particle-phase products of aromatic oxidation, Atmos. Chem. Phys., 20, 9783-9803, https://doi.org/10.5194/acp20-9783-2020, 2020.

Mentel, T. F., Springer, M., Ehn, M., Kleist, E., Pullinen, I., Kurtén, T., Rissanen, M., Wahner, A., and Wildt, J.: Formation of highly oxidized multifunctional compounds: autoxidation of peroxy radicals formed in the ozonolysis of alkenes - deduced from structure-product relationships, Atmos. Chem. Phys., 15, 67456765, https://doi.org/10.5194/acp-15-6745-2015, 2015.

Mohr, C., Lopez-Hilfiker, F. D., Yli-Juuti, T., Heitto, A., Lutz, A., Hallquist, M., D’Ambro, E. L., Rissanen, M. P., Hao, L., Schobesberger, S., Kulmala, M., Mauldin III, R. L., Makkonen, U., Sipilä, M., Petäjä, T., and Thornton, J. A.: Ambient observations of dimers from terpene oxidation in the gas phase: Implications for new particle formation and growth, Geophys. Res. Lett., 44, 2958-2966, https://doi.org/10.1002/2017gl072718, 2017.

Molteni, U., Bianchi, F., Klein, F., El Haddad, I., Frege, C., Rossi, M. J., Dommen, J., and Baltensperger, U.: Formation of highly oxygenated organic molecules from aromatic compounds, Atmos. Chem. Phys., 18, 1909-1921, https://doi.org/10.5194/acp18-1909-2018, 2018.

Molteni, U., Simon, M., Heinritzi, M., Hoyle, C. R., Bernhammer, A.-K., Bianchi, F., Breitenlechner, M., Brilke, S., Dias, A., Duplissy, J., Frege, C., Gordon, H., Heyn, C., Jokinen, T., Kuerten, A., Lehtipalo, K., Makhmutov, V., Petaja, T., Pieber, S. M., Praplan, A. P., Schobesberger, S., Steiner, G., Stozhkov, Y., Tome, A., Trostl, J., Wagner, A. C., Wagner, R., Williamson, C., Yan, C., Baltensperger, U., Curtius, J., Donahue, N. M., Hansel, A., Kirkby, J., Kulmala, M., Worsnop, D. R., and Dommen, J.: Formation of highly oxygenated organic molecules from $\alpha$-pinene ozonolysis: chemical characteristics, mechanism, and kinetic model development, ACS Earth Space Chem., 3, 873-883, https://doi.org/10.1021/acsearthspacechem.9b00035, 2019. 
Nah, T., Sanchez, J., Boyd, C. M., and Ng, N. L.: Photochemical aging of $\alpha$-pinene and $\beta$-pinene secondary organic aerosol formed from nitrate radical oxidation, Environ. Sci. Technol., 50, 222231, https://doi.org/10.1021/acs.est.5b04594, 2016.

Newland, M. J., Bryant, D. J., Dunmore, R. E., Bannan, T. J., Acton, W. J. F., Langford, B., Hopkins, J. R., Squires, F. A., Dixon, W., Drysdale, W. S., Ivatt, P. D., Evans, M. J., Edwards, P. M., Whalley, L. K., Heard, D. E., Slater, E. J., Woodward-Massey, R., Ye, C., Mehra, A., Worrall, S. D., Bacak, A., Coe, H., Percival, C. J., Hewitt, C. N., Lee, J. D., Cui, T., Surratt, J. D., Wang, X., Lewis, A. C., Rickard, A. R., and Hamilton, J. F.: LowNO atmospheric oxidation pathways in a polluted megacity, Atmos. Chem. Phys., 21, 1613-1625, https://doi.org/10.5194/acp21-1613-2021, 2021.

Ng, N. L., Kroll, J. H., Chan, A. W. H., Chhabra, P. S., Flagan, R. C., and Seinfeld, J. H.: Secondary organic aerosol formation from $m$-xylene, toluene, and benzene, Atmos. Chem. Phys., 7, 3909-3922, https://doi.org/10.5194/acp-7-3909-2007, 2007.

Noda, J., Volkamer, R., and Molina, M. J.: Dealkylation of alkylbenzenes: a significant pathway in the toluene, o-, m-, pxylene plus OH reaction, J. Phys. Chem. A, 113, 9658-9666, https://doi.org/10.1021/jp901529k, 2009.

Orlando, J. J., Tyndall, G. S., and Wallington, T. J.: The atmospheric chemistry of alkoxy radicals, Chem. Rev., 103, 46574690, https://doi.org/10.1021/cr020527p, 2003.

Palm, B. B., Campuzano-Jost, P., Ortega, A. M., Day, D. A., Kaser, L., Jud, W., Karl, T., Hansel, A., Hunter, J. F., Cross, E. S., Kroll, J. H., Peng, Z., Brune, W. H., and Jimenez, J. L.: In situ secondary organic aerosol formation from ambient pine forest air using an oxidation flow reactor, Atmos. Chem. Phys., 16, 29432970, https://doi.org/10.5194/acp-16-2943-2016, 2016.

Peng, Z., Day, D. A., Ortega, A. M., Palm, B. B., Hu, W., Stark, H., Li, R., Tsigaridis, K., Brune, W. H., and Jimenez, J. L.: Non-OH chemistry in oxidation flow reactors for the study of atmospheric chemistry systematically examined by modeling, Atmos. Chem. Phys., 16, 4283-4305, https://doi.org/10.5194/acp16-4283-2016, 2016.

Peng, Z., Palm, B. B., Day, D. A., Talukdar, R. K., Hu, W. W., Lambe, A. T., Brune, W. H., and Jimenez, J. L.: Model evaluation of new techniques for maintaining high-NO conditions in oxidation flow reactors for the study of $\mathrm{OH}$-initiated atmospheric chemistry, ACS Earth Space Chem., 2, 72-86, https://doi.org/10.1021/acsearthspacechem.7b00070, 2018.

Rissanen, M. P., Kurtén, T., Sipilä, M., Thornton, J. A., Kangasluoma, J., Sarnela, N., Junninen, H., Jørgensen, S., Schallhart, S., Kajos, M. K., Taipale, R., Springer, M., Mentel, T. F., Ruuskanen, T., Petäjä, T., Worsnop, D. R., Kjaergaard, H. G., and Ehn, M.: The formation of highly oxidized multifunctional products in the ozonolysis of cyclohexene, J. Am. Chem. Soc., 136, 15596-15606, https://doi.org/10.1021/ja507146s, 2014.

Rissanen, M. P.: $\mathrm{NO}_{2}$ suppression of autoxidationinhibition of gas-phase highly oxidized dimer product formation, ACS Earth Space Chem., 2, 1211-1219, https://doi.org/10.1021/acsearthspacechem.8b00123, 2018.

Sarnela, N., Jokinen, T., Duplissy, J., Yan, C., Nieminen, T., Ehn, M., Schobesberger, S., Heinritzi, M., Ehrhart, S., Lehtipalo, K., Tröstl, J., Simon, M., Kürten, A., Leiminger, M., Lawler, M. J., Rissanen, M. P., Bianchi, F., Praplan, A. P., Hakala, J., Amorim, A., Gonin, M., Hansel, A., Kirkby, J., Dommen, J., Curtius, J.,
Smith, J. N., Petäjä, T., Worsnop, D. R., Kulmala, M., Donahue, N. M., and Sipilä, M.: Measurement-model comparison of stabilized Criegee intermediate and highly oxygenated molecule production in the CLOUD chamber, Atmos. Chem. Phys., 18, 23632380, https://doi.org/10.5194/acp-18-2363-2018, 2018.

Sato, K., Takami, A., Kato, Y., Seta, T., Fujitani, Y., Hikida, T., Shimono, A., and Imamura, T.: AMS and LC/MS analyses of SOA from the photooxidation of benzene and 1,3,5trimethylbenzene in the presence of $\mathrm{NO}_{x}$ : effects of chemical structure on SOA aging, Atmos. Chem. Phys., 12, 4667-4682, https://doi.org/10.5194/acp-12-4667-2012, 2012.

Schwantes, R. H., Schilling, K. A., McVay, R. C., Lignell, H., Coggon, M. M., Zhang, X., Wennberg, P. O., and Seinfeld, J. H.: Formation of highly oxygenated low-volatility products from cresol oxidation, Atmos. Chem. Phys., 17, 3453-3474, https://doi.org/10.5194/acp-17-3453-2017, 2017.

Seinfeld, J. H. and Pandis, S. N.: Atmospheric Chemistry and Physics: From Air Pollution to Climate Change, Third Edition, John Wiley and Sons, Inc., Hoboken, New Jersey, 2016.

Tsiligiannis, E., Hammes, J., Salvador, C. M., Mentel, T. F., and Hallquist, M.: Effect of $\mathrm{NO}_{x}$ on 1,3,5-trimethylbenzene (TMB) oxidation product distribution and particle formation, Atmos. Chem. Phys., 19, 15073-15086, https://doi.org/10.5194/acp-1915073-2019, 2019.

Wang, L. M., Wu, R. R., and Xu, C.: Atmospheric oxidation mechanism of benzene. fates of alkoxy radical intermediates and revised mechanism, J. Phys. Chem. A, 117, 14163-14168, https://doi.org/10.1021/jp4101762, 2013.

Wang, M., Chen, D., Xiao, M., Ye, Q., Stolzenburg, D., Hofbauer, V., Ye, P., Vogel, A. L., Mauldin, R. L., Amorim, A., Baccarini, A., Baumgartner, B., Brilke, S., Dada, L., Dias, A., Duplissy, J., Finkenzeller, H., Garmash, O., He, X.-C., Hoyle, C. R., Kim, C., Kvashnin, A., Lehtipalo, K., Fischer, L., Molteni, U., Petäjä, T., Pospisilova, V., Quéléver, L. L. J., Rissanen, M., Simon, M., Tauber, C., Tomé, A., Wagner, A. C., Weitz, L., Volkamer, R., Winkler, P. M., Kirkby, J., Worsnop, D. R., Kulmala, M., Baltensperger, U., Dommen, J., El-Haddad, I., and Donahue, N. M.: Photo-oxidation of aromatic hydrocarbons produces low-volatility organic compounds, Environ. Sci. Technol., 54, 7911-7921, https://doi.org/10.1021/acs.est.0c02100, 2020.

Wang, S., Wu, R., Berndt, T., Ehn, M., and Wang, L.: Formation of highly oxidized radicals and multifunctional products from the atmospheric oxidation of alkylbenzenes, Environ. Sci. Technol., 51, 8442-8449, https://doi.org/10.1021/acs.est.7b02374, 2017.

Wang, Y., Mehra, A., Krechmer, J. E., Yang, G., Hu, X., Lu, Y., Lambe, A., Canagaratna, M., Chen, J., Worsnop, D., Coe, H., and Wang, L.: Oxygenated products formed from $\mathrm{OH}$-initiated reactions of trimethylbenzene: autoxidation and accretion, Atmos. Chem. Phys., 20, 9563-9579, https://doi.org/10.5194/acp20-9563-2020, 2020.

Wu, R., Pan, S., Li, Y., and Wang, L.: Atmospheric oxidation mechanism of toluene, J. Phys. Chem. A, 118, 4533-4547, https://doi.org/10.1021/jp500077f, 2014.

Xu, L., Møller, K. H., Crounse, J. D., Kjaergaard, H. G., and Wennberg, P. O.: New insights into the radical chemistry and product distribution in the $\mathrm{OH}$-initiated oxidation of benzene, Environ. Sci. Technol., 54, 13467-13477, https://doi.org/10.1021/acs.est.0c04780, 2020. 
Yu, J. Z. and Jeffries, H. E.: Atmospheric photooxidation of alkylbenzenes-I I. Evidence of formation of epoxide intermediates, Atmos. Environ., 31, 2281-2287, https://doi.org/10.1016/s1352-2310(97)88637-2, 1997.

Yu, J. Z., Jeffries, H. E., and Sexton, K. G.: Atmospheric photooxidation of alkylbenzenes- I. Carbonyl product analyses, Atmos. Environ., 31, 2261-2280, https://doi.org/10.1016/s13522310(97)00011-3, 1997.

Zaytsev, A., Breitenlechner, M., Koss, A. R., Lim, C. Y., Rowe, J. C., Kroll, J. H., and Keutsch, F. N.: Using collisioninduced dissociation to constrain sensitivity of ammonia chemical ionization mass spectrometry $\left(\mathrm{NH}_{4}^{+} \mathrm{CIMS}\right)$ to oxygenated volatile organic compounds, Atmos. Meas. Tech., 12, 18611870, https://doi.org/10.5194/amt-12-1861-2019, 2019a.

Zaytsev, A., Koss, A. R., Breitenlechner, M., Krechmer, J. E., Nihill, K. J., Lim, C. Y., Rowe, J. C., Cox, J. L., Moss, J., Roscioli, J. R., Canagaratna, M. R., Worsnop, D. R., Kroll, J. H., and Keutsch, F. N.: Mechanistic study of the formation of ringretaining and ring-opening products from the oxidation of aromatic compounds under urban atmospheric conditions, Atmos. Chem. Phys., 19, 15117-15129, https://doi.org/10.5194/acp-1915117-2019, 2019b.
Zhao, Y., Thornton, J. A., and Pye, H. O. T.: Quantitative constraints on autoxidation and dimer formation from direct probing of monoterpene-derived peroxy radical chemistry, P. Natl. Acad. Sci. USA, 115, 12142-12147, https://doi.org/10.1073/pnas.1812147115, 2018.

Zheng, Y., Cheng, X., Liao, K., Li, Y., Li, Y. J., Huang, R.-J., Hu, W., Liu, Y., Zhu, T., Chen, S., Zeng, L., Worsnop, D. R., and Chen, Q.: Characterization of anthropogenic organic aerosols by TOF-ACSM with the new capture vaporizer, Atmos. Meas. Tech., 13, 2457-2472, https://doi.org/10.5194/amt13-2457-2020, 2020.

Ziemann, P. J., and Atkinson, R.: Kinetics, products, and mechanisms of secondary organic aerosol formation, Chem. Soc. Rev., 41, 6582-6605, https://doi.org/10.1039/C2CS35122F, 2012. 